\title{
LOS REGLAMENTOS PARLAMENTARIOS DURANTE EL SEXENIO REVOLUCIONARIO
}

JOSÉ FERNANDO MERINO MERCHÁN

Profesor de Derecho Constitucional Universidad Rey Juan Carlos 


\section{SUMARIO}

I. SigNificaCión CONSTITUCIONAL de LAS Cámaras dURANTE El SEXENIO E IDENTIFICACIÓN DE LOS REGLAMENTOS PARLAMENTARIOS EN VIGOR DURANTE ESE PERIOODO. II. PRINCIPIOS COMUNES A LOS OUE RESPONDEN LOS REGLAMENTOS DEL SEXENIO REVOLUCIONARIO. 1. Autonomía parlamentaria para elaborar y modificar sus propios reglamentos: restricciones en los Reglamentos del Congreso y del Senado de 1867 y profundización en los Reglamentos interino de 1873 y senatorial de 1871. 2. Potestad de autogobierno: eliminación de las interferencias regias. 3. Autonomía administrativa y de régimen interior: su ampliación en los Reglamentos del sexenio. 4. Configuración definitiva en el Reglamento senatorial de 1871 y en el republicano interino de 1873 de la autonomía presupuestaria de las Cámaras. III. EN PARTICULAR:-LOS REgLAMENTOS DEL SEXENIO DE 30 DE JUNIO DE 1871 Y 5 DE AGOSTO DE 1873. 1. Reglamento del Senado de 30 de junio de 1871. A) Preliminar: el Reglamento provisional que había de regir hasta la constitución definitiva del Senado de 4 de abril de 1871 y la vigencia interina del Reglamento de las Cortes Constituyentes de 9 de noviembre de 1854. B) Significado parlamentario del Reglamento del Senado de 30 de junio de 1871: Un producto arquetípico de la Constitución monárquica de 1869. 1. Bicameralismo funcionalmente imperfecto: Prioridad y prevalencia del Congreso en determinadas materias. $2 .^{\circ}$ Senado de representación provincial. 3. ${ }^{\circ}$ Sufragio universal masculino directo por distritos uninominales para el Congreso y sufragio masculino indirecto para el Senado. $4 .^{\circ}$ Renovación íntegra del Congreso y parcial del Senado. C) Relevancia del Reglamento senatorial de 30 de junio de 1871 y sus vicisitudes posteriores. D. Aspectos concretos del contenido del Reglamento de 1871. 1. ${ }^{\circ}$ Control parlamentario de las Actas electorales y la constitución definitiva del Senado monárquico. $2 .^{\circ}$ Constitución de los órganos direccionales en el Reglamento senatorial de 1871.3. ${ }^{\circ}$ Posición institucional de la Presidencia y sus funciones. $4 .^{\circ}$ Los órganos funcionales del Senado: el sistema de Pleno, Secciones y Comisiones. $50^{\circ}$ El procedimiento legislativo y el debate parlamentario en Sesión. $6 .^{\circ}$ El control parlamentario de la acción del Gobierno en el Reglamento senatorial de 1871. 2. Significado parlamentario del Reglamento «interino" de las Cortes Constituyentes republicanas. A) La «proposición» republicana se planteó y aprobó al margen de los esquemas institucionales y reglamentarios en vigor. B) El bicameralismo imperfecto del Parlamento republicano en el proyecto federal de 1873 como marco de referencia del Reglamento «interino" de las Cortes Constituyentes de 1873. C) El Reglamento interino republicano como instrumento de organización y funcionamiento de las Cortes Constituyentes. 3. El fin del sexenio: Reglamentos parlamentarios durante el Gobierno autoritario de Serrano. La vuelta a los Reglamentos isabelinos en la Cámara Baja y mantenimiento del Reglamento senatorial de 1871. 


\title{
LOS REGLAMENTOS PARLAMENTARIOS DURANTE EL SEXENIO REVOLUCIONARIO
}

POR

\author{
JOSÉ FERNANDO MERINO MERCHÁN
}

Profesor de Derecho Constitucional

Universidad Rey Juan Carlos

\section{SIGNIFICACIÓN CONSTITUCIONAL DE LAS CÁMARAS DURANTE EL SEXENIO E IDENTIFICACIÓN DE LOS REGLAMENTOS PARLAMENTARIOS EN VIGOR DURANTE ESE PERIODO}

Durante el período extraordinario de la historia político-constitucional española que discurre entre septiembre de 1868 a 1874, todo resultó, como ha señalado Pavón, imposible: monarquía y república, centralismo y federalismo, la guerra y la paz ni siquiera intentada, acontecimientos todos ellos que acaban remansando con la llegada de la Restauración, que puso fin, aunque sin resolver los problemas de fondo, a un estado de verdadera excepción política.

En efecto, entre el pronunciamiento del 17 de septiembre de 1868 iniciado por Prim y por Topete y el golpe de fuerza del General Pavía dado en la madrugada del día 3 de enero de 1874, se suceden en España sin solución de continuidad la regencia del General Serrano, lo monarquía constitucional de 1869, la «proposición» republicana del 11 de febrero de 1873, que inaugura la primera República en nuestro pais, y de nuevo el Gobierno autoritario de Serrano con que se abría el pronunciamiento del General Pavía. Pues bien, el objeto del trabajo que aqui se expone, va a reducirse a poner de manifiesto y a examinar los 
diferentes Reglamentos parlamentarios habidos durante esa etapa tan convulsa de la historia constitucional española.

Es de observar que así como durante la época de Isabel II los Reglamentos de las Cortes representan los modelos constitucionales postulados entre progresistas y moderados, no puede decirse lo mismo de los Reglamentos parlamentarios del sexenio, en los que salvo el Reglamento del Senado de 30 de junio de 1871, que constituye el arquetipo o paradigma de la monarquía parlamentaria surgida de la Revolución de 1868 , los demás Reglamentos dictados durante esa etapa, o proceden del último período isabelino, como fue el caso del Reglamento del Congreso de los Diputados de 25 de junio de 1867, o se trató de un Reglamento interino republicano para las Cortes Constituyentes como fue el instrumento de 5 de agosto de 1873, o finalmente con la caída del sexenio la vuelta al Reglamento interior del Congreso de los Diputados de 4 de mayo de 1847 con el "macmahonismo" de Serrano.

En definitiva, los instrumentos reglamentarios de que dispusieron las Cámaras durante el sexenio fueron: $1^{\circ}$ ) Durante la monarquía constitucional de 1869, el Reglamento del Congreso de los Diputados de 25 de junio de 1867, que a su vez era tributario en gran medida del de 1847 , y el Reglamento del Senado de 30 de junio de $1871 ; 2 .^{\circ}$ ) Durante la I República, tuvo efímera vida el Reglamento interino de 5 de agosto de $1873 ;$ y $3 .^{\circ}$ ) Finalmente, con la vuelta al régimen autoritario del General Serrano, se restaura en su aplicación el Reglamento interior de 4 de mayo de 1847 para la Cámara Baja, manteniéndose el Reglamento de 30 de junio de 1871 para el Senado.

En consecuencia con lo expuesto, los dos Reglamentos parlamentarios "modélicos" del sexenio revolucionario, serían el Reglamento del Senado de 30 de junio de 1871, que simbolizaría a la Monarquía emanada de los postulados revolucionarios de septiembre de 1868; y por otro lado, el Reglamento de las Cortes Constituyentes de 5 de agosto de 1873, que encarnaría el modelo republicano.

El Reglamento monárquico de 30 de junio de 1871 no dejó de ser, como es natural, trasunto de la Constitusión de 1869, que consagró la Monarquía constitucional en su vertiente radical y democrática. Ya el Manifiesto del Gobierno provisional del General Serrano dado el 25 de octubre de 1869 se decanta por la fórmula monárquica, "pero de cualquier modo - se dirá - el Gobierno provisional si se equivoca en sus cálculos y la decisión del pueblo español no fuese propicia al planteamiento de la fórmula monárquica, respetaría el voto de la soberanía de la Nación debidamente consultada». 
Por primera vez en nuestro constitucionalismo la opción monárquica toma un aspecto exclusivamente "accidentalista", lo que se reflejará de alguna forma en el Reglamento del Senado de 1871. La Monarquía constitucional es aupada como forma de gobierno por el liberalismo radical sólo en la medida que sea compatible con el Estado democrático y representativo surgido de la Revolución de septiembre. La proximidad ideológica y doctrinal con la monarquía instaurada en 1869 con la parlamentaria es casi total. Los dos únicos elementos diferenciadores se encontrarán en los artículos 35 y 54 del Texto constitucional. Por el primero se seguía reconociendo que el poder ejecutivo "reside en el Rey que lo ejerce por medio de sus Ministros". Por el segundo, el Monarca detentaba todavia la iniciativa legislativa junto con las Cámaras.

Es muy probable que de haber tenido más vida el Código político de 1869, habria evolucionado hacia una forma plena de monarquía parlamentaria en el sentido que hoy conocemos a esta última.

Hasta la Constitución de 1869 se había aceptado como vigente el principio denominado de "Constitución interna", bajo el binomio "las Cortes con el Rey", equilibrio siempre roto en beneficio del Rey, porque junto a las extensas atribuciones de orden ejecutivo, tenía amplia influencia en el funcionamiento de las Cámaras (iniciativa, convocatoria, suspensión, disolución y poder sobre el Senado), y en definitiva, además, el Monarca controlaba a través del veto legislativo la función legislativa del Parlamento. En cambio, la Monarquía de 1869, aprovechando el impulso revolucionario y el cambio dinástico, se situará por primera vez en un plano de imparcialidad y neutralidad por encima de las tensiones y luchas de partidos. En este sentido es en el que Sánchez Agesta contrapone Monarquía doctrinaria y democrática: en la primera se aceptan como históricamente dadas la institución monárquica y la representación nacional, ambos elementos serian preexistentes a cualquier configuración política y por ende, compartirian la soberanía; mientras, la Monarquía democrática se fundaría y dependeria exclusivamente de la soberanía nacional que se ejerce por sufragio universal.

Bajo esos principios doctrinales sobre los que se fundamentó el liberalismo radical recogido en la Constitución de 1869, se abre paso el primer régimen verdaderamente democrático de la historia constitucional española. Esto va a tener una profunda repercusión en la configuración y funcionamiento de las Cortes, y por tanto en sus Reglamentos, y que podemos resumir en los puntos siguientes: 
1. La universalización del sufragio universal masculino será la legítima expresión de la soberanía nacional (Preámbulo).

2. El Congreso amplía su base representativa a todos los españoles mayores de edad que gozarán de los derechos civiles; optándose por el sistema de distritos unipersonales. El Senado se mantiene para dar entrada a representantes de la vida municipal y provincial.

3. Limitación de la prerrogativa regia de suspensión de las Cortes. En efecto, el artículo 71 establecía una garantía sin precedentes para mantener en vigor la legislatura, consistente en limitar por "una sola vez en cada legislatura" la prerrogativa regia para suspender las Cortes. Dentro de este mismo espíritu de continuidad del Parlamento la constitución de 1869 exigía que el Real Decreto de disolución contuviera necesariamente la convocatoria de las Cortes para dentro de tres meses. Asimismo se reconocía el principio de reunión automática de las Cortes en los supuestos de vacancia de la Corona y cuando el Rey imposibilitase de cualquier modo el gobierno del Estado.

4. La iniciativa legislativa de las Cámaras no se veía ensombrecida por veto regio alguno. En definitiva, las Cortes ocupan la posición central de todo el sistema político y el Rey pasa a ser un poder constituido.

5. El bicameralismo responde, por primera vez, aunque de forma tímida, a un doble sistema de representación de los intereses generales de la Nación por medio del Congreso y representación provincial a través del Senado.

Es evidente que el Reglamento del Senado de 30 de junio de 1871 , paradigmático como hemos dicho de la Monarquía de 1869, recoja los puntos precedentes como principios dogmáticos del nuevo régimen, como más adelante expondremos.

Por su parte, el Reglamento de 5 de agosto de 1873 encarnaría la doctrina más prístina del régimen republicano surgido tras la renuncia a la Corona por parte de Amadeo de Saboya el 1 de febrero de 1873, y que dio paso el 11 del mismo mes a la forma republicana de gobierno tras la proposición suscrita por Pi, Figueras y Salmerón, y que contó con 258 votos favorables a la propuesta de cambio de régimen y 32 contrarios, siendo así proclamada la I República en España. 
Necesario es destacar en este momento, que en este cambio de régimen se producen dos circunstancias importantes: a) por una parte, como ha escrito Lacomba, se producía "un cambio de régimen sin violencia», con la simple aprobación de un instrumento parlamentario como fue la proposición presentada por los Diputados republicanos aprovechándose del vacío dejado por Amadeo de Saboya al renunciar por sí y por sus hijos y sucesores a la Corona de España; b) pero, por otro lado, justamente por haberse operado el cambio de régimen de la forma descrita, la República no fue traída como escribe Torres del Moral por unas Cortes republicanas tras un proceso constituyente, sino por unas Cortes monárquicas. Lo relevante, desde el punto de vista de este trabajo, consiste en constatar que tan importante cambio de escenario político, se realizó sin sujeción a los Reglamentos en vigor en aquel momento, sino atendiendo exclusivamente a conductas y actos parlamentarios improvisados sobre la marcha.

Más aún, al no llegar a dotarse la I República de una Constitución "ad hoc", las Cortes del régimen republicano de 1873 funcionaron de hecho pero no tuvieron respaldo constitucional alguno (salvo el que le pudo haber otorgado "a posteriorin las elecciones de mayo de 1873), tomando aquí la palabra Constitución en su sentido más formal, puesto que el golpe del General Pavía de 3 de enero de 1874 evitó la aprobación definitiva del Texto constitucional. Con todo, las Cortes previstas en la "non nata" de 1873 representan el mayor reconocimiento del órgano de soberanía popular de la historia constitucional española del siglo XIX, y esto, sin embargo, no tuvo su lógica respuesta en el Reglamento "interino" de agosto de 1873.

Recordemos que las Cortes del régimen político previsto en la Constitución de 1873 reconocían los principios siguientes:

1. Las Cortes representan la soberanía popular que se ejerce mediante sufragio universal, lo que configura a la República como una democracia representativa.

2. Se acoge un bicameralismo imperfecto tanto en el orden competencial como por el reclutamiento de sus miembros. Elio era así por la estructura federal del Estado; el Congreso simbolizaba la unidad de la Nación española: todos los Diputados son elegidos por sufragio universal directo; mientras que el Senado representa la existencia de los Estados regionales: cuatro Senadores por cada Estado forman la Federación. En cuanto a los poderes, el Congreso retenía los tradicionales poderes legislativos; $y$ al Senado, que no tenía la iniciativa legislativa, se le atribuian funciones fiscalizadoras respecto a la legisla- 
ción producida por el Congreso, instituyéndose una suerte de control de constitucionalidad para depurar las normas contrarias a los derechos de la personalidad (art. 70).

Por tanto, no deja de ser llamativo, por contradictorio, el hecho de que se dictase un Reglamento parlamentario para las Cortes Constituyentes republicanas «in absentia constitutionis». Aunque justo es constatar que el carácter de régimen asambleario en el que desembocó el régimen republicano, acabó desbordando también en muchos casos las previsiones reglamentarias.

A la vista de lo expuesto podría parecer que de la misma forma que la Constitución de 1869 supuso un corte súbito y profundo, tanto en el plano político como en el ideológico con respecto a la Constitución isabelina de 1845, y que el posterior paso a una Constitución republicana de corte federativo, implicó un salto hacia adelante en la organización del Estado en la historia constitucional española, todo ello no tuvo, sin embargo, un reflejo profundo en la configuración de los reglamentos parlamentarios vigentes durante el sexenio, como tendremos ocasión de demostrar más adelante. Esto nos hace pensar que en contraste con la tumultuosa historia constitucional española, los Reglamentos parlamentarios guardaron entre sí, por encima de la concepción y del clima político que nacieron, una cierta similitud y un "cuerpo común", lo que acabó otorgando a las Cámaras de una relativa estabilidad en su funcionamiento, por encima de los avatares políticos subyacentes.

La razón de la semejanza interna entre los reglamentos parlamentarios hay que buscarla en que se trata de instrumentos normativos que venían recogiendo las prácticas parlamentarias que de forma continuada incorporaban los hábitos, costumbres y pautas que se daban en Inglaterra desde mediados del siglo XVIII y en Europa desde principios del siglo XIX. Hay que recordar a este respecto que las Asambleas representativas han venido pugnando desde el medievo por el reconocimiento del derecho a su autogobierno mediante convenciones y usos internos, que garantizasen su independencia frente al monarca absoluto y más tarde frente al poder ejecutivo. La permanente reivindicación a reunirse libremente, nombrar a sus órganos de gobierno y a dictar sus normas de funcionamiento sin interferencias de poderes externos, son aspectos que se empiezan a configurar en el Derecho parlamentario español ya en el Reglamento de $1838^{1}$, al socai-

1 Marcuello Benedicto, J. I.: "Los Reglamentos de las Cortes en la época de Isabel Il", Revista de las Cortes Generales, n. ${ }^{\circ}$, 1985. 
re de la Constitución liberal-moderantista de 18 de junio de 1837, en la que se reconoció sin ambages que "cada uno de los Cuerpos colegisladores forma el respectivo reglamento para su gobierno interior" (art. 29). Es a partir de este momento cuando los reglamentos parlamentarios se empiezan a elaborar sin participación alguna del poder ejecutivo, autorregulándose su gobierno interior y el funcionamiento de las Cámaras.

Será el Reglamento interior del Congreso de los Diputados de 4 de mayo de 1847, el que ya de forma definitiva recoja la potestad autorreglamentaria y autopotestativa de las Cámaras, Reglamento que, por cierto, define el carácter modélico de los Reglamentos isabelinos ${ }^{2}, y$ que sirvió de fundamento no sólo a los reglamentos posteriores de esa época, sino también al Reglamento republicano de 5 de agosto de 1873, y que, incluso, después de quedar superada la etapa del sexenio volvió a estar en vigor, con reformas hasta 1918 en la Cámara Baja española; este último recogió a su vez muchos elementos de aquél y, en definitiva el Reglamento de 1918 ha sido el que, a su vez, nos ha llegado hasta los Reglamentos provisionales de 1977, dando paso finalmente a los de 1982.

Quiere decirse que, ya desde 1847 , con mayor o menor fortuna e intensidad, en función de los principios políticos e ideológicos a los que sirvieron, los reglamentos parlamentarios que arrancan desde el de 1847 y en particular el de 25 de junio de 1867, el de 5 de agosto de 1873 (para el Congreso de los Diputados) y el de 30 de junio de 1871 (para el Senado), todos ellos participan de un conjunto de principios comunes, formando entre todos eilos un "núcleo común de normas» sólo alterado por algunas novedades que otorgan a cada Reglamento parlamentario su perfil político específico.

\section{PRINCIPIOS COMUNES A LOS QUE RESPONDEN LOS REGLAMENTOS DEL SEXENIO REVOLUCIONARIO}

Ya se ha dicho más atrás que el régimen de la monarquía constitucional de 1869 no dispuso de un reglamento "ad hoc" para el Congreso de los Diputados, sino que se aplicó el último reglamento de la época isabelina de 25 de junio de 1867; y que por el contrario, la Cáma-

2 Para Marcuello Benedicto, en cambio, fue el Reglamento del Congreso de 1838 el que tuvo carácter modélico durante la etapa isabelina, vid. op. cit. infra. 
ra Alta sí se dotó en uso de su potestad autonormativa del Reglamento de 30 de junio de 1871. Y en cuanto al régimen político de la I República, el Congreso se autodotó del Reglamento de 5 de agosto de 1873, manteniéndose en vigor durante esa etapa en el Senado el Reglamento de 1871 antes citado. Pues bien, el grado de madurez en la elaboración de los reglamentos indicados hace posible que podamos hablar de principios comunes a todos ellos, dentro de un margen de gradualidad. Estos principios se esbozan a continuación.

1. Autonomía parlamentaria para elaborar y modificar sus propios reglamentos: restricciones en los Reglamentos del Congreso y del Senado de 1867 y profundización en los Reglamentos interino de 1873 y senatorial de 1871

La autonomía parlamentaria se concibe históricamente como un freno para salvaguardar la libertad de las Cámaras que permita establecer y reservar un ámbito propio para ejercer libremente las funciones que constitucionalmente se les atribuyen.

En efecto, la autonomía normativa del Parlamento recibió temprana declaración constitucional en el artículo 1, Sec. V.2 de la Constitución de Estados Unidos de 1787, al proclamarse que "each house may determine the Rules of its own proceedings". Y será precisamente la Constitución gaditana de 1812 la que reconozca en el ámbito europeo ese derecho de las Cámaras (art. 127: «en las discusiones de las Cortes, y en todo lo demás que pertenezca a su gobierno y orden interno, se observará el Reglamento que se forme por estas Cortes Generales y extraordinarias, sin perjuicio de las reformas que las sucesivas tuviesen por conveniente hacer en él».

Por tanto, mediante la autonomía se da cobertura a dos aspectos importantes de la vida parlamentaria: a) mantener la independencia de la organización y funcionamiento de los procesos decisorios de las Asambleas frente al poder ejecutivo; y b) permitir sin restricciones la participación plural de los parlamentarios en el proceso de formación de la voluntad, para conformar a las Cámaras como órgano esencialmente deliberante. Ambos aspectos constituyen una auténtica reserva parlamentaria sobre un conjunto de materias como son: funcionamiento interno (convocatoria, reuniones, régimen de acuerdos, publicidad de sesiones), facultades inherentes a las Cámaras (iniciativa legislativa, tramitación de las proposiciones de ley y no de ley) y articulación del control del Gobierno por las Cámaras (régimen de 
interpelaciones y preguntas, y con el paso del tiempo, mediante un sistema de depuración política, aparecen los instrumentos de control con responsabilidad política, esto es, moción de confianza y de censura).

Ciertamente los reglamentos en vigor durante el sexenio no se manifiestan todos con la misma intensidad a la hora de proclamar la autonomía parlamentaria. En este sentido, los más restrictivos serán, como es lógico fueron, los Reglamentos del Congreso de los Diputados y del Senado de 1867, que como hemos dicho se aplicaron en ambas Cámaras hasta que aparecieron el Reglamento republicano de 1873 para el Congreso y en 1871 para el Senado, puesto que encontraban fuertes limitaciones en la propia Constitución isabelina de 1845, que aunque recogía en su artículo 28 que "cada uno de los Cuerpos Colegisladores formaba su propio reglamento", lo cierto era que tal declaración se veía oscurecida por otros preceptos constitucionales. Así, el artículo 31 declaraba que «la apertura y cierre de las Cortes era una potestad atribuida al Rey, que la ejercía por sí mismo o por medio de sus Ministros». O el propio artículo 26, que afirmaba que "la convocatoria y suspensión, así como la disolución del Congreso de los Diputados, corresponde al Rey en exclusivan. No obstante esto último, el Congreso de los Diputados disponía de resortes suficientes para plantear la reforma del reglamento siguiendo los trámites de las proposiciones de ley (vid. artículos 216 y 196 de los Reglamentos de 1847 y 1867).

Como es lógico, tanto el Reglamento del Senado de 30 de junio de 1871 como el republicano de 5 de agosto de 1873 del Congreso, profundizan en la autonomía parlamentaria más allá de las nuevas formalidades, ya que, aunque se mantiene la dicción literal de que la reforma del reglamento "seguirá los trámites de una proposición de ley", lo cierto es que en ese procedimiento, tanto en la creación como en la modificación de la norma parlamentaria no intervendrá ni fáctica ni legalmente el poder ejecutivo.

\section{Potestad de autogobierno: eliminación de las interferencias regias}

Como consecuencia del anterior principio se fue asentando primero tímidamente en los reglamentos isabelinos y después definitivamente en los posteriores, el principio de la autonomía de gobierno interior de las Cámaras.

Es evidente que durante la etapa isabelina y sobre todo en lo concerniente al Senado, la Cámara Alta carecía de potestad para designar 
a su propio Presidente y a las Mesas, al tratarse de una Cámara sometida enteramente a la voluntad regia. De esta forma, mientras que el Congreso elegía autónomamente su Presidente, Vicepresidente Y Secretarios (art. 29 de la Constitución de 1845), en cambio, correspondía al Rey nombrar en cada legislatura, de entre los mismos Senadores, el Presidente y Vicepresidente del Senado y éste elegía a sus Secretarios (art. 30).

Esa interferencia en la potestad para designar por las Cámaras sus propios órganos de dirección, se interrumpe definitivamente con las Constituciones de 1869 y en el régimen de la I República. En el primer caso, el artículo 45 de la Constitución de la monarquía española de 1869, se decía que: «cada uno de los Cuerpos Colegisladores nombrará su Presidente, Vicepresidentes y Secretarios...n. Precepto constitucional que tendrá su proyección en los artículos 33 y siguientes del Reglamento senatorial de 30 de junio de 1871. Y en el segundo caso, aunque no llegó a promulgarse la Constitución republicana, el Reglamento de 5 de agosto de 1873 se dejaba resuelta de forma nítida la elección del Presidente, Vicepresidentes y Secretarios por la propia Cámara ( vid. artículos 8 a 12 y 28). Por consiguiente puede afirmarse que en los dos Reglamentos paradigmáticos del sexenio (senatorial de 1871 y republicano de 1873) acaba por desaparecer definitivamente la interposición de la voluntad regia en el autogobierno de las Cámaras.

\section{Autonomía administrativa y de régimen interior: su ampliación en los Reglamentos del sexenio}

Como consecuencia del reconocimiento de la potestad autoorganizativa y autorreglamentaria, surge en los reglamentos decimonónicos la llamada autonomía administrativa y de régimen interior, que consiste en atribuir al Presidente de las Cámaras poderes y facultades de policía en el interior de la sede parlamentaria. Esta atribución no tiene otro significado que el de impedir que ningún otro poder o cualquier órgano estatal ajeno a las Cámaras puedan intervenir en estas materias.

Bajo la denominación de potestad administrativa y de régimen interior se comprende un haz de facultades un tanto dispersas. Así, por un lado, las referidas a la propia seguridad (protección y vigilancia) de las sedes del Congreso y del Senado, facultades que se atribuyen exclusivamente al Presidente de la respectiva Asamblea. Pero también se extiende a las cuestiones de personal y a los contratos que las 
Cámaras deban celebrar con terceros. Tradicionalmente la autonomía en materia de personal ha significado que cada Cámara reclutase y designase a sus propios funcionarios, dando lugar a cuerpos y organizaciones separadas del resto de la burocracia estatal, y por ello, disponiendo también de su propio Estatuto funcionarial.

Precisamente serán los reglamentos isabelinos $(1847,1854$ y 1867, todos del Congreso de los Diputados) -además de incorporar las técnicas formales de las preguntas, interpelaciones, proposiciones no de ley - los que reconocerán la autonomía administrativa y de régimen interior de las Cámaras como se manifiesta en los artículos 210 y siguientes; 148 y siguientes y 191 y siguientes de los Reglamentos del Congreso de 1847, 1854 y 1867, respectivamente. En este sentido, El Reglamento del Senado de 30 de junio de 1871, del régimen monárquico de 1869, no hace sino profundizar en estas cuestiones (véanse sus artículos 230 y siguientes), recogiéndose incluso una especifica mención al papel del Letrado Mayor (art. 1. ${ }^{\circ}$, como destinatario de recibir las certificaciones de las actas originales que debían remitir al Senado las juntas electorales de cada provincia). Y en este mismo sentido, el Reglamento republicano de 5 de agosto de 1873 atribuirá al Presidente de las Cortes la policía de la sede y del edificio en que celebran sus sesiones, "quien dará al efecto las órdenes oportunas a los empleados en el y al Jefe de la Guardia si lo hubiese" (art. 163).

\section{Configuración definitiva en el Reglamento senatorial de 1871 y en el republicano interino de 1873 de la autonomía presupuestaria de las Cámaras}

Por último, también tomando como punto de partida los reglamentos de la etapa isabelina, la autonomía financiera y presupuestaria de las Cámaras quedará definitivamente configurada con el Reglamento del Senado de 30 de junio de 1871 y de las Cortes Constituyentes republicanas de 5 de agosto de 1873, como elemento fundamental para que los cuerpos representativos ejerzan sus funciones constitucionales sin interferencias económicas o financieras de órganos extraños al Parlamento. Pues, es claro, difícilmente las Cámaras podrían controlar y fiscalizar al Gabinete o Gobierno si no contase con los recursos materiales y económicos precisos.

Una limitación o dependencia en este aspecto tan esencial no haría sino colocar a las Asambleas bajo la voluntad de otras instancias, que son precisamente las llamadas a ser controladas, lo cual pugnaba 
abiertamente con el principio democrático que se asienta ya como dogma ideológico en la Constitución de 1869 y en el régimen asambleario en el que acabó convirtiéndose el régimen político republicano.

En consecuencia, más allá del mero planteamiento formal o semántico que al respecto recogían los reglamentos isabelinos, lo cierto es que. la dependencia sustantiva de los Cuerpos colegisladores - en particular el Senado, vitalicio y enteramente sometido a la voluntad regia - impidió llevar hasta sus últimas consecuencias durante ese periodo el principio de autonomía presupuestaria y financiera de las Cámaras. En cambio, al concebirse el régimen constitucional de 1869 como una monarquía parlamentaria, derivada del sufragio universal, y por tanto como un "poder derivado o constituido" con plena división de poderes y reconocimiento de los derechos individuales de las personas como derechos naturales y previos a cualquier poder, propiciará que el Reglamento senatorial de 1871 en aplicación del artículo 45 de la Constitución incorpore en todo su plenitud el presupuesto anual de los gastos del Senado que "percibirá y administrará" (vid. artículo 234). $Y$ por las mismas razones, aunque en este caso sin una cobertura constitucional expresa, aunque con fundamento en el papel asambleario de las Cámaras,el Reglamento republicano de las Cortes Constituyentes de 1873 repetirá pari passu la misma expresión - "percibirá y administrará los fondos»- (véase su artículo 166).

\section{EN PARTICULAR: LOS REGLAMENTOS DEL SEXENIO DE 30 DE JUNIO DE 1871 Y 5 DE AGOSTO DE 1873}

\section{Reglamento del Senado de $\mathbf{3 0}$ de junio de $\mathbf{1 8 7 1}$}

A) Preliminar: el Reglamento provisional que había de regir hasta la constitución definitiva del Senado de 4 de abril de 1871 y la vigencia interina del Reglamento de las Cortes Constituyentes de 9 de noviembre de 1854

Al iniciarse la Legislatura de 1871-1872 se adoptó a propuesta del Senador Ortiz de Pinedo como Reglamento del Senado el de las Cortes Constituyentes de 9 de noviembre de $1854^{3}$, con algunas modificaciones poco significativas.

3 Diario de Sesiones, n. 2, de 4 de abril de 1871. 
El producto normativo resultante se denominó «Reglamento provisional que ha de regir hasta la constitución definitiva del Senado". El acuerdo quedó adoptado en los términos siguientes:

«EI Sr. PRESIDENTE: Señores, hay otra cuestión también que tengo que someter al Senado.

Por el Reglamento provisional que hemos acordado, en su artículo adicional se previene que para la constitución del Senado, y en lo sucesivo hasta que se dé un nuevo Reglamento, se regirá esta Cámara por el de 1854, con las modificaciones que se hicieron. La Mesa ha examinado este Reglamento, y cree que se pueden hacer en él algunas modificaciones muy ligeras, porque, aun cuando se presta grandemente á muchas modificaciones, esas vendrán en el Reglamento definitivo, y por ahora propone sólo las que cree de absoluta necesidad en el momento, las cuales se van á leer, se repartirán también impresas a los Sres. Senadores para discutirse mañana, y sobre ellas podrá hacer igualmente el Senado las adiciones, reclamaciones y observaciones que estime oportunas" 4 .

En realidad se trataba de aprobar una disposición parlamentaria por la que se pudiera nombrar una Mesa interina que examinase las Actas electorales de los Senadores electos, al tiempo que establecer un mínimo de pautas para canalizar los debates en sesión y todo ello con carácter provisorio hasta que se produjese la constitución definitiva de la Cámara Alta.

El control de las Actas y credenciales de los electos se atenía escrupulosamente a lo establecido en el Reglamento de las Cortes Constituyentes de 1854; pero en cambio se modificaba este último en aspectos concretos tales como: $\left.1 .^{\circ}\right)$ el quórum para abrir la sesión exigía la presencia de 30 Senadores (en vez de 50 del Reglamento de 1854), y para tomar resoluciones sería suficiente con la presencia de 40 , siempre que éstas no tuvieran el carácter de ley; $2^{\circ}$ ) se alteraba el artículo 2 del Reglamento de 1854 en el sentido de que la votación para la Mesa sería por papeletas, que los Senadores llamados por lista entregarán al Presidente, el cual las depositará en una urna... "considerando que este método ofrece algunas irregularidades, para evitarlas, la Mesa propone que se sustituya por el establecido en el artículo 116 del Reglamento del Senado de 11 de mayo de 1866, que previene que los Senadores permanezcan en su puesto, y pasando dos porte-

4 Diario de Sesiones, n. ${ }^{\circ}$, de 13 de abril de 1871. 
ros por ambos lados del Senado con urnas, recojan las papeletas, que depositará en ellas cada Senador, y concluida esta operación serán las urnas depositadas en la mesa para el escrutinio».

Las insuficiencias de todo tipo planteadas por este Reglamento provisional dio paso a la necesidad de que la Cámara Alta contase con una norma estatutaria que estuviese en consonancia con la Constitución de 1869, por eso, se formuló una proposición de reforma al "provisional", que acabó siendo aprobada por el Pleno el 30 de junio de 1871 , dándose lugar así al séptimo Reglamento del Senado que entró en vigor el 11 de julio de $1871^{5}$, y al que dedicaremos nuestra atención inmediatamente.

B) Significado parlamentario del Reglamento del Senado de 30 de junio de 1871: Un producto arquetípico de la Constitución monárquica de 1869

La revolución de septiembre que puso final al reinado de Isabel II, dio lugar a las nuevas Cortes Constituyentes que elaboraron la Constitución de 1869. La nueva Ley Fundamental configuraba, en síntesis, las Cortes Generales en los términos siguientes:

1. Bicameralismo funcionalmente imperfecto: Prioridad y prevalencia del Congreso en determinadas materias

Como era de esperar se plantó una vez más en nuestra historia constitucional la polémica monocameralismo-bicameralismo. Aunque en contra de lo que pudiera esperarse la controversia fue de tono menor - sobre todo si lo comparamos con los tensos debates sobre la cuestión en las Constituyentes de 1812-, la razón de este relativo desinterés, pudo venir dado, según apunta Fernández Segado, por el agotamiento que produjo entre los diputados el extenso debate sobre la libertad de cultos y sobre la forma de gobierno.

De esta forma se llegó a la aprobación del artículo 38, a cuyo tenor "Las Cortes se componen de dos Cuerpos Colegisladores, a saber: Senado y Congreso. Ambos cuerpos son iguales en facultades,

5 Diario de Sesiones, $n .^{\circ} 57$, de 30 de junio de 1871, y $n .{ }^{\circ} 64$, de 11 de julio de 1871. 
excepto en los casos previsto en la Constitución". Reconociéndose en el artículo 45 a ambas Cámaras potestad autorreglamentaria y autoorganizativa.

Lo interesante es resaltar que no se establecía un bicameralismo perfecto desde el punto de vista funcional, porque se daba prioridad al Congreso sobre el Senado en las importantes materias siguientes: proyectos de ley sobre contribuciones, crédito público y fuerza militar. En estos casos, según preveía el artículo 50, la prioridad del Congreso se transformaba en prevalencia, ya que si aquella Cámara hacía alguna alteración que esta última no aceptaba, prevalecía la resolución del Congreso. Esta es una de las razones por las que sorprende que el Senado se dotase de un reglamento parlamentario y no lo hiciese el Congreso.

\section{Senado de representación provincial}

Se ha señalado por la doctrina que la razón por la que se mantuvo una segunda cámara en contra de los principios radicales de la Revolución de 1868 fue, la novedosa idea de conferir al Senado representación, junto a los intereses generales, los locales; dándose entrada en la representación a los elementos de la vida municipal y los de la vida provincial.

A este fin servía el artículo 60, a cuyo tenor "los senadores se elegirán por provincias. Al efecto, cada distrito municipal elegirá por sufragio universal un número de compromisarios igual a la sexta parte de Concejales que deban componer un Ayuntamiento". Aqui puede encontrarse la necesidad que tuvo el Senado monárquico de 1869 de configurarse tan pronto como pudo de sus instrumentos estatutarios (el Reglamento provisional de 4 de abril y el definitivo de 3 de agosto de 1871).

3. Sufragio universal masculino directo por distritos uninominales para el Congreso y sufragio masculino indirecto para el Senado

El artículo 65 determinaba que «el Congreso se compondrá de un diputado al menos por cada 40.000 almas de población, elegido con arreglo a la Ley electoral».

El derecho de sufragio pasivo era extensible al activo; es decir, eran elegibles todos los españoles mayores de edad que gozaran de todos los derechos civiles (art. 66). 
La Ley Electoral de 23 de junio de 1870, a la cual se remitia la Constitución, optó por el sistema de distritos unipersonales. Cada provincia se desdoblaba en tantos distritos electorales cuantos fuesen los diputados que se debieran elegir, resultando electo en cada distrito el candidato que hubiese obtenido mayor número de votos.

El artículo 66 de la Constitución al que hemos hecho referencia, encontraba también concreción digna de todo encomio en el artículo $4 .^{\circ}$ de la Ley Electoral de 1870 al decir que «son elegibles para diputados a Cortes todos los electores".

En consecuencia, sufragio universal masculino directo para ser elector y elegido.

En cambio, el Senado, contrariamente a lo que parecía evidente conforme el espíritu revolucionario, aun dando un gran paso en su democratización, se mantuvo dentro de la representación indirecta. En efecto, los artículos 60 a 64 de la Constitución regulaban la elección del Senado, que como ya hemos dicho más atrás se elegian por provincias (art. 60), mediante el sistema de compromisarios, los cuales constituian las Juntas electorales, cada una de las cuales elegía a pluralidad absoluta de votos cuatro senadores.

La condición de elegido no era universal, como en el caso del Congreso, sino que se establecían para ser elegido Senador requisitos cualificados que limitaban extraordinariamente su acceso: $\left.1 .^{\circ}\right)$ ser español; $\left.2 .^{\circ}\right)$ tener cuarenta años; $3^{\circ}$ ) gozar de todos los derechos civiles, y $4.0^{\circ}$ reunir alguna de las siguientes condiciones: ser o haber sido Presidente del Congreso; Diputado electo en tres elecciones generales, o una vez para Cortes Constitucionales; Ministro de la Corona; Presidente del Consejo de Estado, de los Tribunales Supremos; Capitán General del Ejército o Almirante; Embajador; Consejero de Estado; Arzobispo u Obispo; Rector de la Universidad; Catedrático de término con dos años de ejercicio; Presidente o Director de las Academias Españolas; Diputado provincial cuatro veces; Alcalde dos veces en pueblos de más de 30.000 almas; además, eran elegibles los 50 mayores contribuyentes por contribución territorial, y los 20 mayores por subsidio industrial y comercial de cada provincia (arts. 62 y 63 ).

Como ha subrayado Sánchez Agesta, el Senado de 1869 quedó como un último refugio del sentido minoritario del doctrinarismo. Las tendencias federalistas y republicanas en las Constituyentes lucharon por implantar el sufragio universal directo y el carácter definitivamente federal del Senado, pero la mayoría parlamentaria impuso su criterio 
de Cámara de representación indirecta con concesión a la representación provincial; se pretendía imitar con esto último a Suiza y a Estados Unidos, pero el carácter de Estado unitario impedía trasplantar a España los modelos federales y confederales. Sería la Constitución de 1873, que nunca llegó a aprobarse, la que plasmaría el modelo americano.

Todo ello daba lugar a que la Alta Cámara tuviera, como dicen Fernández Segado y Tomás Villarroya, una naturaleza compleja, pues por razón de su origen, era de elección popular; por razón de su composición, era una asamblea seleccionada; y por razón de su naturaleza, tenía una cierta dimensión federal.

\section{Renovación íntegra del Congreso y parcial del Senado}

Otra característica típica de las Cortes de la Constitución de 1869, venía dada por la disimilitud en la renovación de ambas Cámaras. EI Senado tenía sentido de permanencia frente al Congreso que se renovaba totalmente cada tres años; en cambio aquél lo hacia por cuartas partes cada tres años (art. 39), salvo que fuera disuelto por el Rey, en cuyo caso la renovación del Senado era total.

Por lo que se refiere al funcionamiento de las Cámaras, la Constitución de 1869 recogia los principios siguientes:

\section{a) Principio de reunión anual}

El artículo 42 decía que «las Cortes se reúnen todos los años. Corresponde al Rey convocarlas, suspender y cerrar sus sesiones $y$ disolver uno de los Cuerpos Colegisladores, o ambos a la vez".

\section{b) Principio de sesiones interanuales}

Con al fijación de períodos de sesiones de «a lo menos cuatro meses cada año" y el "rigor legis» de que el Rey las convocase "a más tardar, para el $1 .^{\circ}$ de febrero", se pretendía evitar períodos intersesionales excesivamente largos que pudieran perjudicar el papel central que en el sistema jugaban las Cortes. 
c) Limitación de la prerrogativa regia de suspensión de las Cortes

El artículo 71 establecía una garantía sin precedentes para mantener en vigor la legislatura, consistente en limitar por "una sola vez en cada legislatura" la prerrogativa regia para suspender las Cortes. Una vez ejercitada esa prerrogativa en una legislatura, el Rey, si volviera a hacer uso de la misma, debería solicitar el consentimiento de las Cortes.

\section{d) Principio de disolución con convocatoria}

Dentro del mismo espíritu de mantener viva la continuidad del Parlamento, órgano que representaba la soberanía nacional ejercitada por sufragio universal, se situaba el artículo 72 para el caso "de disolución de uno o ambos Cuerpos Colegisladores, el Real Decreto contendrá necesariamente la convocatoria de las Cortes para dentro de tres meses".

La disolución sin condiciones en manos del Rey podía constituir un secuestro de la soberania nacional, de aquí la ratio legis de ese precepto que se conectaba con el artículo 32 que hacía residir la soberanía nacional en la Nación, de la cual emanaban todos los poderes.

\section{e) Principio de reunión automática}

Siguiendo con al misma filosofía, la Constitución legitimaba la reunión automática de las Cortes, en determinados supuestos: a) cuando vacase la Corona, y b) cuando el Rey imposibilitase de cualquier modo el gobierno del Estado. En estos casos «las Cortes se reunirán necesariamente» (art. 44).

\section{f) Principio de simultaneidad pero con deliberación separada}

Finalmente, el artículo 46 prohibía que estuviese reunido uno de los Cuerpos colegisladores sin que lo estuviese también el otro. Haciéndose una excepción para el caso uen que el Senado se constituya en Tribunalı. Excepción, por lo demás, justificable, pues en tal función el Senado no estaba en ejercicio de atribuciones parlamentarias. 
El principio de simultaneidad no implicaba deliberación conjunta, sino antes al contrario la mayor garantía del "pleno funcionamiento parlamentario" exigía que las Cámaras se reuniesen por separado aunque en el mismo período de tiempo. A este principio respondía el artículo 47.

Precepto ese último que llevado del proverbial celo sobre la independencia del Parlamento, prohibía la deliberación en presencia del Rey. Viejo mecanismo de autodefensa frente al Rey que por las características y naturaleza del régimen constitucional de 1869 resultaba absolutamente irrelevante.

Es en este contexto político y parlamentario en el que se abre la Cámara Alta la Legislatura de 1871-1872, que adoptó, merced a la proposición del Senador Ortiz de Pinedo, como Reglamento el de las Cortes Constituyentes de 1854 con levísimas alteraciones como hemos visto más atrás. Sin embargo, muy pronto se presentó una proposición de reforma de ese reglamento que tras su correspondiente tramitación dio lugar a que el 30 de junio de 1871 (con el breve interregno del provisional de 4 de abril de 1871), se efectuase su aprobación definitiva, entrando en vigor de esta manera el 11 de julio de 1871 el séptimo Reglamento del Senado 6 .

El nuevo reglamento marca un hito en la Cámara Alta, ya que estuvo en vigor hasta 1918, siendo por tanto, el de más larga vigencia en el Senado con más de 40 años de vida.

\section{C) Relevancia del Reglamento senatorial de 30 de junio de 1871 y sus vicisitudes posteriores}

El Reglamento senatorial de 1871 configura una planta completa de lo que fue la vida, funcionamiento y prácticas parlamentarias del último tercio del siglo $X I X$ y comienzo del siglo $X X$ y que afectó a materias tales como: control interno de las Actas electorales y constitución definitiva de la Cámara, elección autónoma de sus órganos direccionales (Presidente, Vicepresidentes y Secretarios), establecimiento más garantista para el procedimiento legislativo, configuración de un calendario fijo para el ejercicio del control político al Gobierno mediante las

6 Vid. Ripollés Serrano, R., Reglamentos del Senado 1834-1993, Senado, 1993. 
correspondientes preguntas, interpelaciones y proposiciones de ley, incorporándose además un concepto bastante avanzado del voto de censura y de confianza. También es interesante señalar que bajo el Reglamento senatorial de 1871 se instrumentó el Estatuto del Personal funcionario de la Cámara, sirviendo de precedente para los posteriores.

El Reglamento senatorial de 1871 que sirvió a regímenes políticos tan distintos como la monarquía constitucional de 1869 y la Restauración de 1876, sufrió a lo largo de su dilatada vida las vicisitudes siguientes: no hubo modificaciones en la Legislatura de $1872 \mathrm{ni}$ en 1872-1873, período en que la abdicación del Rey electo Amadeo de Saboya, el 11 de febrero de 1873, propició la reunión conjunta de ambas Cámaras -en clara vulneración como hemos indicado del artículo 47 de la Constitución de 1869-que proclamaron la I República española. En ese momento el Reglamento de 1871 se dejó literalmente en suspenso. Las nuevas Cortes Constituyentes se abrieron el 1 de junio de 1873 y el 17 de julio se presentó el Dictamen de la Comisión encargada de elaborar el proyecto constitucional - proyecto de constitución federal de la República Española- que no llegó a finalizar su tramitación por disolución de las Constituyentes mediante Decreto de la Presidencia de la República de 8 de enero de 1874 y la constitución de un Ministerio de Regencia?.

\section{D) Aspectos concretos del contenido del Reglamento de 1871}

1. Control parlamentario de las Actas electorales y la constitución definitiva del Senado monárquico

El Reglamento senatorial de 1871 se mantuvo fiel a la tradición del Derecho público español en la que, el control sobre la validez de las Actas y Credenciales de los electos a las Cámaras legislativas estaba sometida a la fiscalización de las propias Asambleas, dentro de un mal concebido principio de independencia y autonomía del Parlamento frente a los demás poderes del Estado. Ha sido precisamente el artículo 70.2 de la vigente Constitución de 1978 quien ha roto por primera vez en nuestra historia constitucional esa tendencia, al recoger el control jurisdiccional para el examen de la validez de las Actas electorales de

7 Ripollés Serrano, R., op. cit., pág. 33. 
los electos al Parlamento. El fundamento de este cambio, se encuentra en que bajo la Constitución española de 1978 no hay zonas exentas al control jurisdiccional (arts. 117.3 y $24.1 \mathrm{CE}$ ).

Con todo y dentro de esa tendencia histórica, el Reglamento senatorial de 1871 en uso de las facultades que le habilitaba el artículo 45 de la Constitución de 1869, estableció por primera vez un auténtico y riguroso control interno parlamentario sobre el examen de las actas y actitud legal de los senadores electos, estableciéndose para ello el procedimiento recogido en los Títulos III y IV de ese Reglamento de 1871 , a alguno de cuyos aspectos nos referiremos a continuación.

En efecto, en la primera Legislatura de cada renovación total o parcial, y en la sesión del mismo día en que se constituía interinamente la Cámara, ésta nombraba la llamada Comisión Permanente de Actas, compuesta de siete individuos, además de otra Comisión auxiliar con el mismo número.

La Comisión auxiliar examinaba y emitía dictamen respecto de las actas de los individuos de la Comisión Permanente; y si alguna o la actitud legal del elegido presentaba dificultad, aunque fuese leve, el Senado, sin discusión previa, le sustituía con otro Senador efectivo o electo cuya acta y aptitud legal no ofreciese duda alguna. Los dictámenes de esa Comisión auxiliar eran los primeros que se discutían y votaban.

Por su parte, la Comisión Permanente examinaba las actas originales con toda la documentación que la Secretaría del Senado hubiese recibido en virtud de lo dispuesto en le artículo 159 de la Ley Elec-

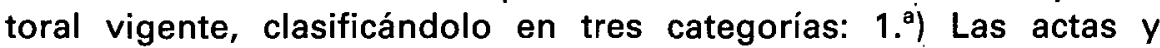
credenciales que no contuviesen protesta ni reclamación; $\left.{ }^{a} .^{9}\right)$ las que sólo ofrezcan motivos ligeros de discusión, y 3.") las que ofrezcan dificultad grave.

De las actas comprendidas en cada una de las dos primeras categorías, se daba cuenta de ello en dos listas separadas, expresando la provincia que corresponda en cada acta y el nombre de los electos, y proponiendo al Senado que las apruebe y proclamase Senadores electos a los individuos incluidos en dichas listas. Tras la discusión correspondiente en el Pleno del Senado, el Presidente proclamaba Senadores a los electos asi propuestos.

Por el contrario, si del examen de un acta y su documentación resultase haber ocurrido en la elección alguno de los hechos considerados como punitivos por la Ley Electoral, la Comisión proponía que se pasase el tanto de culpa al tribunal o juzgado competente por con- 
ducto del Gobierno, acordando el Senado no expedir la correspondiente credencial.

2. Constitución de los órganos direccionales en el Reglamento senatorial de 1871

Una vez terminado el examen de las actas de primera y segunda categoría, si resultaban admitidos la mitad más uno de los Senadores electos, se procedía de inmediato a la constitución definitiva de la Cámara Alta, principiándose con las elecciones internas para Presidente, Vicepresidentes y Secretarios.

La elección del Presidente, Vicepresidentes y Secretarios se verificaba en los términos previstos en los artículos 213, 214, 215 y 216 del Reglamento, que mandataban que toda elección de personas se hiciese por papeletas. Estas votaciones se verificaban permaneciendo cada Senador en su puesto y pasando dos porteros por ambos lados del salón con sus urnas a recoger las papeletas, procediéndose a continuación al escrutinio.

Resultaba ser elegido Presidente el Senador que hubiese obtenido mayoría absoluta, y si no hubiese obtenido esa mayoría en la primera votación se procedía a la segunda entre los dos senadores que hubiesen obtenido mayor número de votos. Si aún resultase empate, quedaba nombrado el de mayor edad.

El procedimiento descrito se ha mantenido luego en todos los reglamentos posteriores, llegando con ligerísimas variantes has los reglamentos vigentes de 1982.

Concluidas las votaciones, los elegidos ocupaban sus puestos y el Presidente declaraba haberse constituido definitivamente los órganos del Senado, dándose cuenta de ello al Congreso y al Gobierno.

\section{Posición institucional de la Presidencia y sus funciones}

Superadas las limitaciones institucionales impuestas por la Monarquía isabelina para la Cámara Alta, es en el Reglamento senatorial de 1871 cuando en puridad puede calificarse al Presidente de la Cámara como máxima autoridad dentro del recinto parlamentario. Puede decirse que hasta este Reglamento la Presidencia de la Cámara Alta había tenido escaso o nulo poder, tanto por las interferencias regias como por la resistencia de los Senadores vitalicios a ceder pode- 
res o competencias a ningún órgano. En consecuencia, la etapa que se inicia con el Reglamento senatorial de 1871 y hasta la II República puede ser calificada como la "etapa dorada» de las Presidencias de las Cámaras, ya que con la aparición de los grupos parlamentarios en el período de la II República la Presidencia de la Cámara se atenúa en favor de las llamadas Mesas fuertes con el propósito de colegiar y debilitar los poderes presidenciales unipersonales.

Pero, como decimos, no fue este el caso de la Presidencia del Senado en el Reglamento de 1871, en el que sin género de dudas, el Presidente pasa a ser considerado como la máxima autoridad de la Asamblea.

Reflejo de este status del Presidente del Senado es el conjunto de funciones y atribuciones que el Reglamento le atribuye en su Título VII y que se fundamentan no sólo en su carácter electivo autónomo, sino también por ostentar la «representación de la Cámara dentro y fuera de la misman.

En un intento de sistematizar el conjunto de funciones atribuidas al Presidente del Senado, se puede formular el cuadro siguiente:

\section{a) Funciones de representación constitucional}

Además de la función de representación institucional, el Presidente del Senado en el Reglamento de 1871 tenía una relevante función relacional con el Rey y los demás órganos del Estado, pudiéndose destacar:

- Presidir las llamadas Comisiones de Etiqueta y de Mensajes al Rey.

- Firmar las Actas del Senado y los proyecto de ley y mensajes que se dirijan al Rey o al Congreso.

- Firmar los mensajes y proyectos de ley que se dirijan al Rey, así como los que se dirijan al Congreso.

- Comunicar al Gobierno el orden del día.

b) Funciones relativas a la organización y dirección de las Cámaras y los debates parlamentarios

- Dirigir los actos del Senado con sujeción a las prescripciones del Reglamento. 
- Abrir, suspender y cerrar las sesiones; y determinar los días en que no deba haberlas.

- Fijar el orden del día y la prelación de los asuntos que en ella deban discutirse.

- Dirigir las discusiones conforme al Reglamento.

- Conceder o denegar, según proceda, el uso de la palabra.

- Dar el curso correspondiente a las proposiciones que en forma reglamentaria presenten los Senadores.

- Fijar en caso de duda los puntos sobre los que se ha de votar.

\section{c) Funciones disciplinarias}

Como correlato del grupo de funciones antes descrito, se le atribuyen al Presidente importantes potestades disciplinarias que se desplegaban en un triple sentido:

- Conservación del orden en las discusiones parlamentarias.

- Facultad de advertir por tres veces a los Senadores para que se concretasen al orden del día y a la cuestión, pudiendo: 1) retirar la palabra; 2) llamar al orden a quien falte al Reglamento o interrumpa al orador o falten el respeto debido al Presidente, y 3) privar del uso de la palabra al Senador que hubiese sido llamado al orden tres veces.

- Ejercer las atribuciones de policía del Senado y de su sede, dictando al efecto las órdenes oportunas a los empleados y al Jefe de la guardia militar si lo hubiese (vid. artículo 231).

- Finalmente, si se cometiese algún delito dentro del Palacio del Senado, podía el Presidente «mandar detener a los culpados y entregarlos a disposición del Tribunal competente...n.

\section{d) Funciones interpretativas}

Se ha escrito que la función interpretativa que el Reglamento atribuye al Presidente de la Cámara constituye el paradigma de sus atribuciones parlamentarias. En efecto, será a partir del Reglamento senatorial de 1871 y con fundamento precisamente en su artículo 46.12 ("y hacer uso conveniente de las demás atribuciones que le otorga el 
Reglamento, aunque no aparezcan enumeradas en este artículon) cuando se irá desarrollando la práctica - luego más tarde recogida expresamente - de otorgar al Presidente de la Cámara la función específica de zanjar las situaciones conflictivas o dudosas que se planteen entre los parlamentarios. Esta función acabará siendo la fuente de todas las demás competencias, y por tanto, la más relevante.

Como el despliegue histórico del Reglamento senatorial de 1871 fue muy largo en el tiempo, fue asentándose como una realidad sustantiva la función interpretativa lato sensu de la Presidencia, comprendiendo tres esferas de atribuciones. La primera haciendo cumplir las normas internas del Parlamento; entendiendo dentro de las mismas tanto el propio Reglamento como el conjunto de usos y convenciones que se agregan a la letra escrita del instrumento reglamentario; ello tanto praeter como secundum legem. La segunda atribución es la de interpretar en caso de duda el Reglamento, lo que empezó a entenderse como una simple consecuencia obligada de su "auctoritas" acabó siendo un hecho incontestable para los parlamentarios; atribución, que por cierto, corrió en paralelo también con la manifestación del carácter más fuerte o más débil de la Presidencia. Y, finalmente, el tercer aspecto de la función interpretativa en sentido amplio, comprendió también en las prácticas parlamentarias que se desenvolvieron en torno al Reglamento de 1871, la de "poder suplir el Reglamento en los casos de omisión".

Huelga decir que la función interpretativa que acabó asumiendo la Presidencia del Senado bajo el Reglamento de 1871 no estaba sometida a control alguno, al considerarse una expresión nítida de los interna corporis, exentos de fiscalización alguna.

\section{e) Funciones de control y de calificación de la Presidencia}

Con el paso del tiempo y el desarrollo alcanzado por el Parlamento moderno, la función de control y de calificación ha venido a constituirse en la más transcendente e importante de todas sus competencias, trasvasándose su contenido y ejercicio a las propias Mesas, que se han acabado configurando como las defensoras del orden público constitucional y parlamentario en sede asamblearia.

No se encuentra en el Reglamento de 1871 una atribución específica de control y calificación a favor del Presidente de la Cámara Alta, pero es evidente que la potestad que le atribuía el artículo $46.7 .^{\circ}$ ( «dar el curso correspondiente a las proposiciones que en forma reglamen- 
taria presenten los Senadores") dio lugar durante la intensa vida parlamentaria de la restauración y en la que estuvo en vigor este Reglamento, a que, poco a poco, se fuera configurando a favor del Presidente de la Cámara una típica función de control y de calificación, lo que le permitió atribuciones tales como las de examinar y pronunciarse sobre la admisibilidad o inadmisibilidad de los documentos presentados a la Cámara Alta, o rechazar enmiendas que no guardasen los requisitos formales o materiales prescritos reglamentariamente.

\section{Los órganos funcionales del Senado: el sistema de Pleno, Secciones y Comisiones}

Otra de las grandes manifestaciones del Reglamento senatorial de 1871 es la de que acabó consagrando el sistema de Pleno, Secciones y Comisiones que se había iniciado en la etapa isabelina, como órganos destinados a cumplir las competencias que la Constitución de 1869 otorgaba al Senado.

Al reconocer la Constitución de 1869 la plena soberanía parlamentaria de las Cámaras, acabó tomando pleno sentido el concepto de Pleno como la reunión de todos los miembros que componen la Cámara Alta debidamente convocados encarnando la representación nacional. Desde esta perspectiva el Pleno del Senado al ser el órgano funcional de mayor relevancia quedaba revestido de determinadas garantías formales para la apertura, toma de acuerdos y cierre de sesiones. Asi, el Presidente abría la sesión bajo la fórmula Abrese la sesión y la cerraba con la de Se levanta la sesión, por lo que una vez pronunciada esa última expresión no se permitía hablar a ningún Senador y se reputaba nulo cuanto se hiciese. Asimismo, se disponía reglamentariamente que las sesiones debían de durar al menos dos horas, siendo necesario para abrir las mismas estar presentes treinta Senadores cuando menos, bastando cuarenta para toda resolución que no sea la votación definitiva de proyectos de ley, en cuyo caso se aplicaba el artículo 51 de la Constitución que mandataba que "las resoluciones de las Cortes se tomarán a pluridad de votos. Para votar las leyes se requiere en cada uno de los Cuerpos Colegisladores la presencia de la mitad más uno del número total de los individuos que tengan aprobadas las Actas".

Fuera de esas exigencias formales, el Pleno del Senado en uso de sus atribuciones constitucionales, podía acordar cualquier resolución, incluida la suspensión de sus Sesiones por uno o más días, 
bien que se adoptase este acuerdo autónomamente o a petición del Gobierno.

Se observa pues, que en el Reglamento senatorial de 1871 ya está presente la centralidad del Pleno y que se manifiesta a través básicamente de la potestad legislativa como someramente veremos más adelante.

Por lo que se-refiere a las Secciones, el Reglamento de 1871 establecía que la misma sesión en que habían quedado elegidos los cargos de Presidentes, Vicepresidentes y Secretarios, se procedia a dividir a todos los Senadores en siete Secciones de igual número, verificándose para ello un sorteo, que se renovaba de nuevo bimensualmente. Es de reconocer que esta forma de actuación obviaba por completo el principio de especialización y permanencia propio de los Parlamentos modernos. En todo caso, cada Sección elegía autónomamente a su Presidente, Vicepresidente y Secretario, dando cuenta de esos nombramientos a la Secretaría del Senado; siendo preciso la concurrencia de al menos diez Senadores para celebrar Sección, salvo que transcurridos quince minutos desde la hora señalada no compareciese ninguno más, en cuyo caso se podía iniciar la Sesión.

Al constituirse la Sección como el órgano funcional de trabajo más importante, se admitía la asistencia en las mismas de los Ministros de la Corona, pudiendo únicamente emitir voto el que fuera también Senador en la Sección a la que perteneciese.

Por lo demás, las funciones atribuidas a las Secciones eran, entre otras, las siguientes:

- Nombrar a los individuos que han de componer las Comisiones de trabajo, que no podían estar formadas por más de siete personas.

- Examinar y autorizar la lectura de las proposiciones sometidas a su examen.

- Elevar al Pleno los proyectos de ley examinados en su seno.

En las Comisiones, como tercer órgano funcional, hay que destacar que en el Derecho parlamentario español decimonónico, concretamente desde el Reglamento de 1810, la función preparatoria e instructora primaria del procedimiento legislativo se llevaba a cabo a través de estos órganos. Ya durante la época de Isabel II se superó la discrecionalidad con la que contaba la Presidencia de cada Cámara para nombrar los miembros de las Comisiones (asi, esta era la regla en los Reglamentos de 1834), por ello el Reglamento senatorial de 1871 
en èste aspecto no hizo sino seguir las pautas marcadas en los Reglamentos del Congreso de 1838 y 1847 y del Senado de 1847, 1866 y 1867 , en el sentido de vincular el nombramiento de los miembros de las Comisiones a las Secciones, adoptando el criterio que ya hemos expuesto más atrás (véase así la dicción literal del artículo 83 del Reglamento de 1871: "Las Comisiones serán siempre elegidas por las Secciones...n). Además, es el Reglamento que estamos comentando el que clasificará las Secciones en no permanentes y permanentes. Las primeras se disolverán "luego que quede definitivamente votado el asunto sometido a su examen" (art. 85). Las segundas son aquellas que se constituyen durante toda la legislatura, y que eran: De Actas, de Fomento, de Gobierno Interior, de Presupuesto, de Examen de Cuentas Generales del Estado, de Nombramiento y Separación de Miembros del Tribunal de Cuentas del Reino, de Inspección de la Deuda Pública, de Concesión de Gracias o Pensiones, de Peticiones y de Corrección de Estilo.

Cada Comisión, constituida por siete individuos, nombraba su Presidente y Secretario y para realizar sus tareas podían contar con personas ajenas al Senado.

\section{El procedimiento legislativo y el debate parlamentario en Sesión}

La función legislativa constituyó durante todo el siglo XIX y bien entrado el XX, la función más clásica y arquetípica del Parlamento, hasta el punto que esa función ha dado históricamente nombre a este poder del Estado como "Poder Legislativo".

Pues bien, como es lógico, tanto la Constitución de 1869 como el Reglamento senatorial de 1871 se desenvolvieron en este punto bajo esa tradición y, es más, participaron también del liberalismo doctrinario que arranca de 1837 y llega hasta 1931, según el cual la potestad legislativa reside en las Cortes con el Rey.

Según esa fórmula doctrinaria, el artículo 54 de la Constitución de 1869, la iniciativa legislativa era compartida con el Rey y cada uno de los Cuerpos Colegisladores. Si bien es cierto que bajo la efímera vigencia de la Constitución de 1869, la fase constitutiva (deliberación y aprobación de los proyectos), no sufrió interferencias regias y lo mismo puede decirse respecto a las proposiciones de ley presentadas por los Senadores que hubiesen sido tomadas en consideración. Por lo demás, durante esta fase de tramitación legislativa los proyectos de ley se sometian a una triple lectura: $\left.1 .{ }^{a}\right)$ Examen del proyecto por el 
Pleno del Senado; ${ }^{2} .^{\text {) }}$ a continuación por la Sección y nombramiento de la Comisión que haya que estudiarlo, y $3 .^{\text {a) }}$ Vuelta al Pleno para la aprobación definitiva. Debiéndose tener en cuenta que la disolución del Senado o del Congreso daba "por terminados cuantos trabajos pendieran en el Senado" (art. 130 del Reglamento).

En lo concerniente a la fase integradora es donde más se aprecia el carácter diferencial de la Monarquía parlamentaria de 1869 respecto de los regimenes anteriores, en las que el Rey en uso de su potestad de sanción podía rechazar el proyecto de ley aprobado en fase plenaria; en cambio, bajo la Constitución de 1869 y el Reglamento de 1871 el Rey se limitaba estrictamente a sancionar el producto legislativo aprobado por las Cámaras.

La organización de los debates en el procedimiento legislativo en el Reglamento de 1871, se organizaba conforme a los criterios siguientes:

- En los dictámenes de mucha extensión e importancia, se procedia a la discusión primero en la totalidad y después por artículos o párrafos. El debate general recaía sobre el principio, espíritu y oportunidad del proyecto, sin que se pudiese cerrar ninguna discusión parlamentaria general sin que hubiesen hablado tres Senadores en contra y otros tantos en pro, salvo lo dispuesto en el propio Reglamento para casos especiales. En el supuesto de que ningún Senador hubiese pedido la palabra en contra del proyecto se procedía sin más a la votación del mismo (arts. 132 a 136). En los proyectos de Códigos, además de su discusión en totalidad, cabía realizar varias discusiones generales por libros, títulos o capitulos, siempre que así lo acuerde el Senado, a propuesta de su Presidente o a petición de un Senador.

- Los votos particulares se presentabáan dentro de las veinticuatro horas siguientes de haberse leído el dictamen y se discutían por el orden siguiente: En primer lugar lo que se referían a la totalidad del proyecto de ley o proposición; y a continuación lo que afectasen a uno o más artículos. El voto particular era defendido por el autor o uno de sus autores siendo contestado por uno de los individuos de la mayoría de la Comisión. Rechazado o incorporado el voto particular se procedía a la discusión o debate de los artículos. Por lo que se refiere a las enmiendas estaban sometidas a una doble lectura: En la primera se examinaban sus requisitos de admisibilidad y en la segunda se discutía la oportunidad de 
incorporarla al artículo al que afectase. Para ello se concedía la palabra al autor de la misma o a uno de sus autores, que eran contestados por un individuo de la Comisión, resolviéndose a continuación mediante votación, si ésta era negativa quedaba desechada.

- Concluida la discusión y votación de un proyecto de ley o de una proposición, la Secretaría lo redactaba conforme con lo acordado, siendo revisado posteriormente por la Comisión de corrector de estilo, siendo sometido, a continuación, a la aprobación definitiva. El uso de la palabra en la Sesiones plenarias se sujetaba al principio de contradicción $y$ alternancia, esto es, primero se defendía el proyecto o la proposición por el Senador o Senadores designados al efecto y luego a continuación contestaban los que se manifestaban en contra. Ningún Senador podía hablar sin que hubiese pedido públicamente la palabra y le fuese concedida. Los Ministros podían intervenir en cualquier momento de la discusión, siempre que hubiesen pedido el uso de la palabra, haciendo uso de ella pero sin consumir su turno. En todo caso y en cualquier estado de la discusión se podía solicitar por un Senador la observancia del Reglamento, citando los artículo cuya aplicación reclame, y la lectura de los mismos si le conviene (arts. 159 y siguientes del Reglamento).

$Y$, finalmente, las votaciones para aprobar o rechazar los asuntos y proyectos o proposiciones debatidas, podían adoptar cualquiera de los cuatro modos siguientes:

1. Levantándose los que aprueban y quedándose sentados los que reprueben.

2. Por votación nominal, que tenía lugar siempre que computados los votos por cualquier otro procedimiento resultase que la diferencia entre los que aprueben y reprueben no pase de uno, o cuando lo pidiesen al menos siete Senadores. Esta votación se verificaba diciendo los Senadores sus nombres y añadiendo al ser llamados "sí» o "no", según fuese el voto de aprobación o desaprobación.

3. Por papeletas, que tenía lugar cuando se trataba de elección de personas. Permanecía cada Senador en su escaño y pasando dos porteros por ambos lados del salón con sus urnas se recogían las papeletas, procediéndose por la Mesa a su escrutinio. 
4. Por bolas. Esta forma de votación se realizaba cuando se pretendiese enjuiciar o calificar los actos o la conducta de una persona, y también cuando el Senado lo acordase por mayoría de dos terceras partes (arts.' 206 y siguientes del Reglamento).

En todo caso y conforme mandataba el artículo 51 de la Constitución de 1869, para la votación definitiva de las leyes se requería la presencia de la mitad más uno del número total de Senadores que tuviesen aprobadas sus actas (art. 259 del Reglamento).

\section{El control parlamentario de la acción del Gobierno en el Reglamento senatorial de 1871}

La doctrina especializada ha resaltado que las primeras manifestaciones de la moción de confianza y de censura, que tuvieron lugar en el parlamentarismo español, ocurrieron durante la vigencia del Estatuto Real. En efecto, el 31 de diciembre de 1835 el Ministro Mendizábal solicitó el voto de confianza para su Gobierno; y el día 21 de mayo de 1836 tuvo lugar la presentación del primer voto de censura contra un gobierno, cuando Istúriz fue objeto de una declaración de no confianza por una petición cursada por 68 procuradores; el voto de censura prosperó y, consecuentemente con ello, un Decreto de 22 de mayo disolvía las Cortes.

Hay que llamar la atención sobre lo meritorio de la aparición tan temprana de estas instituciones de control parlamentario sin la existencia de normas reguladoras al respecto y sin precedentes patrios previos. Esto demuestra, una vez más, que el Derecho parlamentario, lejos de estar cosificado y atado a la simple literalidad, es una rama viva del conocimiento jurídico apegada a las prácticas y a los usos políticos que tienen lugar en sede parlamentaria. También merece la pena recordar ahora que, no obstante la falta de previsiones en los Reglamentos parlamentarios de la primera etapa isabelina, ello no fue óbice para que apareciesen, al margen de los cauces previsto, las técnicas de control de las preguntas y de las proposiciones.

Más tarde y ya bajo los sucesivos desarrollos reglamentarios que tuvo la Constitución de 1845, las Cortes isabelinas dispusieron de tres vehículos reglamentarios para ejercitar el control parlamentario de la acción de Gobierno: $10^{\circ}$ ) la contestación al discurso de la Corona, que significaba un juicio de valor con cierto grado de fiscalización del programa político del Gobierno; $2^{\circ}$ ) la vía de la proposición no de ley, que 
abría un debate de política general y que podía terminar en una moción de confianza o de censura, y $3 .^{\circ}$ ) las interpelaciones.

Durante los primeros años del Régimen isabelino - en particular durante la década moderada - la oposición parlamentaria recurrió con frecuencia al recurso de la Contestación al Discurso de la Corona, para propiciar un debate parlamentario abierto sobre el «programa de Gobierno". Más tarde, primero en el bienio progresista (1854-1856), y después en la década de los años sesenta se acudió a la proposición de ley para provocar declaraciones de apoyo o rechazo del Gobierno.

Bajo los principios democráticos de la Monarquía constitucional de 1869, los instrumentos de control sobre el Gobierno se intensificaron, pasándose de una fiscalización difusa a otra más intensa y permanente. De hecho, es bajo el Reglamento parlamentario que examinamos donde por primera vez puede apreciarse con cierta nitidez la tipología del control parlamentario del Gobierno. Esto es, el llamado control sin responsabilidad política, que implica una función fiscalizadora de mera adecuación de la actividad político-administrativa del Gobierno a la Constitución y al programa político del mismo; y el control con responsabilidad politica, que supone una función fiscalizadora por la cual la Cámara realiza una manifestación de voluntad, concretada en una resolución por la que se otorga o no la confianza al Gobierno. Analizaremos por separado dicha tipología.

a) Las manifestaciones del control sin responsabilidad politica en el Reglamento senatorial de 1871 fueron:

1. Solicitud de información

El artículo 103 facultaba a las Comisiones para reclamar del Gobierno "cuantos documentos y noticias crean necesario para el acierto en sus dictámenes».

Con esa solicitud el Senado pretendía ilustrarse o conocer materias sobre las que carecía de información o ésta era insuficiente. La solicitud de información que con el devenir de los años se ha constituido en una pieza esencial en las relaciones Gobierno-Parlamento, apareció ligada durante el régimen político monárquico de 1869 y después durante la Restauración a los debates legislativos, extendiéndose más tarde a los presupuestarios; y constituyó ya desde este momento una pieza importante para poder ejercer los demás instrumentos de control (preguntas, interpelaciones y mociones). 
2. Comparecencia de Ministros y de otras personas que podían ser llamadas al Senado

El artículo 104 autorizaba al Senado a llamar a los Ministros y a otras personas "para concurrir a sus Sesiones". De aquí se derivó la práctica de que los parlamentarios recabasen de los miembros del Gobierno y de otras personas presentes no miembros de la Cámara, información sobre el funcionamiento de los Departamentos que dirigían a los que se encontraban adscritos.

\section{Las preguntas parlamentarias}

Las preguntas son seguramente los instrumentos de control más tradicionales de las Cámaras, a través de las cuales pueden solicitar $y$ obtener el esclarecimiento de diversas materias de la competencia $y$ ámbito del Gobierno.

Históricamente aparecen y se desarrollan en los Parlamentos medievales, mediante la forma de peticiones al Rey; precisamente en esas peticiones está el protorigen de las preguntas parlamentarias y también de la iniciativa legislativa. Con la llegada del constitucionalismo decimonónico, las Cartas otorgadas robustecieron, por ser éste el único medio de control existente a fin de que el Monarca por medio de las mismas pudiese adoptar medidas especificas ante problemas concretos. Este fue, por ejemplo, el planteamiento seguido en el Estatuto Real de 1834 y en los Reglamentos de los Estamentos de Próceres y Procuradores, ambos de 1834, también.

Bajo la Constitución isabelina de 1845 las preguntas acaban configurándose como los instrumentos idóneos para controlar al Gobierno, primero en los Reglamentos de 1834 y luego en los de 1847, de Congreso y Senado, respectivamente. Y será, definitivamente, el Reglamento senatorial de 1871 quien acabará por perfilar las preguntas casi en la forma en que hoy se conciben. Así, su artículo 190 preceptuará que "los Senadores pueden también dirigir preguntas al Gobierno sobre asuntos de interés público, a que aquél contestará, si lo tuviere por conveniente, ya en el acto, ya aplazando la contestación, y sobre ellas, aunque sean contestadas, no habrá discusión".

\section{Las interpelaciones}

En el Derecho constitucional español histórico, salvo la Constitución de 1869 (art. 53), no aparece reconocida la interpelación. Sin 
embargo, la institución era conocida y regulada en los Reglamentos parlamentarios que se dictan desde 1838 por ambas Cámaras.

En la práctica parlamentaria, las interpelaciones son un tipo de preguntas dirigidas al Gobierno sobre materias de carácter general o de particular relieve político, y que suelen provocar la apertura de un debate que eventualmente puede terminar con la presentación de una moción o proposición. Todos estos elementos ya están presentes en el régimen jurídico configurador de las interpelaciones en el Reglamento de 1871. Ya que, en primer lugar, se facultaba a todo Senador para poder interpelar a los Ministros de palabra o por escrito, debiendo indicar el objeto de la interpelación (art. 186). El Ministro del ramo podía contestar en el acto o señalando el día en que estaba dispuesto a hacerlo (art. 187).

Finalmente, en el día señalado para la interpelación, el Senador exponía los términos de la misma en la forma más conveniente; replicaba el Gobierno; y sólo se admitía que interviniese en el debate otro Senador más, pasándose a continuación al siguiente asunto (art. 188).

Pero lo relevante era que, como ocurre en la actualidad «de resultas de la interpelación", podían los Senadores presentar las correspondientes proposiciones.

\section{Las proposiciones o mociones generales}

Las proposiciones no de ley o mociones generales suelen constituir un acto subsiguiente de control respecto de las preguntas e interpelaciones parlamentarias, motivadas por contestaciones insatisfactorias dadas por el Gobierno ante cuestiones concretas presentadas por los parlamentarios. El fundamento específico de las proposiciones o mociones generales se encuentra en que, a diferencia de las preguntas e interpelaciones, implican casi siempre un acuerdo final deliberativo dirigido al ejecutivo. La proposición no de ley como técnica de control parlamentario se utilizó por primera vez bajo la Constitución moderantista-liberal de 1837 y estando en vigor el Reglamento del Congreso de 1838, derribándose el Gobierno de Antonio González ${ }^{8}$.

Así es como aparece ya configurado este instrumento de control en el Reglamento de 1871 cuando recogía en su artículo 180 que "si

8 Diario de Sesiones de las Cortes, Legislatura 1841-1842, n. ${ }^{\circ} 126$, sesión de 28 de mayo de 1842. 
durante una discusión se hiciese una proposición... el Senado acordará lo que juzgue oportuno". Dado el carácter relevante que como técnica fiscalizadora adoptan las proposiciones no de ley o mociones generales, se veían necesitadas de la firma de siete Senadores.

6. Las enmiendas y adiciones de los mensajes al Rey

El Reglamento de 1871 recogiendo prácticas reglamentarias que se habían utilizado en la etapa isabelina y que aparecen incluso reflejada en alguno de sus Reglamentos (1847, 1854 y 1867 del Congreso), autorizó una forma específica de control sin responsabilidad al reconocer a los Senadores el derecho a presentar enmiendas y adiciones en los mensajes que el Senado dirigía al Rey, siempre que estos mensajes fueran votados previamente en sesión plenaria. En cuyo caso, los Senadores presentes podian hacer uso de tal facultad. El Pleno del Senado a la vista de las enmiendas y adiciones decidía las que debían ser admitidas, que a continuación pasaban a ser discutidas para, en su caso, incorporarlas al mensaje (arts. 192 a 194).

\section{La contestación al discurso de la Corona}

Hasta 1931 el Parlamento dispuso -ya hemos expuesto más atrás la utilización que se hizo de este medio fiscalizador- de un específico control difuso y sin responsabilidad respecto de los discursos de la Corona, cuya contestación se discutía sólo en su totalidad (art. 152), pero mediante la constitución de una Comisión previa que emitía su dictamen a los tres días de su nombramiento, permaneciendo durante dos más sobre la Mesa, para inmediatamente proceder a su discusión, en la que intervenían tres Senadores en contra y tres a favor.

Si como consecuencia del debate se presentaban enmiendas al dictamen, se admitían sólo las dos que, a juicio de la Mesa, se apartasen más de él. A continuación se procedía a la votación de las mismas.

b) El control con responsabilidad política en el Reglamento senatorial de 1871

El control parlamentario con responsabilidad política es una función fiscalizadora de las Cámaras que empieza a perfilarse en la vida parlamentaria española durante la etapa isabelina e implica una declaración plenaria sobre el otorgamiento o no de la confianza al Ejecutivo. El perfil definitivo de esta institución acabará conformado bajo las prácticas nacidas en el Reglamento de 1871. 
En efecto, las preguntas, como las interpelaciones y las mociones generales eran - como hemos visto - y son en la actualidad manifestaciones de un control parlamentario vago y difuso que no implican consecuencias inmediatas, porque a través de sus instrumentos no se emite un juicio de valor plenario sobre el otorgamiento o no de la confianza al Gobierno. En cambio, en los actos parlamentarios con responsabilidad política, se pone en juego la continuidad del Gobierno mediante una declaración sancionatoria o aprobatoria de las Cámaras. Es bajo esta perspectiva como nació el control con responsabilidad en Inglaterra en los albores de la Monarquía parlamentaria y, concretamente en 1739, cuando Walpole, Jefe del Gabinete, se reconoce responsable ante la Cámara de los Comunes y es sometido a votación por esta última por tal motivo; y más adelante, en 1782, en congruencia con el precedente Walpole, se produce la dimisión de Lord Worth. Esta invención de los ingleses, como la llamaría Loewenstein, sustituiria las previas y toscas formar de responsabilidad meramente penal que se ejercitaba por medio de la acusación (impeachment), usada por el Parlamento contra los consejeros y funcionarios del Rey desde 1376.

En definitiva, el control parlamentario con responsabilidad encuentra su justificación ideológica en el propio sistema representativo y democrático, esto es, en la insoslayable idea de que el Parlamento es el único titular de la soberanía; lo que se traduce finalmente en el principio de que los gobernantes están al servicio de los gobernados.

No es de extrañar, por tanto, que sea bajo los auspicios doctrinales de la Monarquía constitucional de 1869 y de su Reglamento arquetípico de 1871 el que recogiese en su Título XXIV los llamados votos de censura y de gracias. La recepción de estos tipos de control parlamentario en el Reglamento del Congreso de 1847 -que en cambio no aparece en el Reglamento senatorial del mismo año-, constituía una previsión que rebasaba doctrinal e ideológicamente la Constitución moderada de 1845, creándose en ese Reglamento 1847 un vehículo formal para que el Congreso ejercitase una facultad no reconocida expresamente por la Ley Fundamental9.

9 Esto debió ser así tanto por las experiencias parlamentarias a las que ya se ha aludido y que tuvieron lugar a propósito de la moción de confianza del Ministerio de Mendizábal de 31 de diciembre de 1835, y a la de censura contra el Gobierno de Istúriz de 21 de mayo de 1836; como la ocurrida en 1842 cuando una coalición de progresistas antiesparteristas utilizó la vía de la proposición no de ley para formular un voto de censura contra D. Antonio González (vid. infra, nota pág. 8). 
Pues bien, la Comisión encargada de redactar el Reglamento senatorial de $1871^{10}$, consideró que bajo los fundamentos doctrinales en que se apoyaba la nueva Monarquía surgida de la Revolución de septiembre, cabría utilizar con mayor utilidad política los preceptos reglamentarios que sin soporte institucional alguno, habían sido recogidos en el Reglamento del Congreso de 1847. Esta es la razón por la que los artículos 195 y 196 del Título XXIV del Reglamento senatorial de 1871 reprodujeron literalmente la configuración de los votos de censura y de gracia como instrumentos de control con responsabilidad política, que, además contaban con el respaldo constitucional del artículo 53 del Código Político de 1869 que otorgaba a «ambos Cuerpos Colegisladores... el derecho de censura y a cada uno de sus individuos el de interpelación"; e incluso del artículo 58.4 que atribuía a las Cortes (in genere) el "hacer efectiva la responsabilidad de los ministros". Cierto es también que la corta vida del régimen monárquico constitucional de 1869 no dio lugar a un desarrollo pleno de estos vehículos de control; pero gracias a la prolongada vigencia del Reglamento del Senado de 1871 y a las prácticas parlamentarias incorporadas durante la Restauración permitieron que estos instrumentos de control acabasen teniendo cierta virtualidad político-jurídica.

El esquema formal del funcionamiento de los votos de censura y de gracias en el Reglamento de 1871 se concretaba en los requisitos siguientes:

1. Que el voto de censura se formulase por escrito y que fuese firmado por siete Senadores (art. 195).

2. Cumplidas esas exigencias formales el voto de censura se tramitaba como una proposición no de ley pasando a las Secciones correspondientes para su aprobación o rechaza (art. 195).

Más allá de lo expuesto, no decía nada el Reglamento de 1871; pero es de suponer que esos trámites eran suficientes para "activar" el procedimiento de control. En efecto, presumiblemente si la Sección encargada de informar el voto de censura se manifestaba de acuerdo con ella, el Pleno manifestaría también su apoyo con la consecuencia de hacer dimitir al Gobierno censurado.

10 Diario de Sesiones, $n .^{\circ} 35,25$ de mayo de 1871, y Debates en Pleno de los días 30 y 31 de mayo y $1,2,3,5,6,7$ y 9 de junio de ese mismo año. Ver también Diario de Sesiones, $n .^{\circ} 57$ y n. $^{\circ} 64$, de 30 de junio y 11 de julio de 1871. 
Por su parte, el artículo 196 del Reglamento introducía una importante matización en la tramitación de los llamados votos de gracias y de censura, que deberían estar revestidos de la misma exigencia formal -suscritos por la firma de siete Senadores-, se discutian en el Pleno del Senado pero sin pasar a las Secciones y sin Dictamen de Comisión.

\section{Significado parlamentario del Reglamento «interino» de las Cortes Constituyentes republicanas}

A) La "proposición» republicana se planteó y aprobó al margen de los esquemas institucionales y reglamentarios en vigor

Ya hemos dicho como el 1 de febrero de 1873 entregó a Amadeo de Saboya a Ruiz Zorrilla, como Presidente del Consejo de Ministros, un mensaje dirigido al Congreso de los Diputados. El Presidente de la Cámara, Rivero, leyó el mensaje en el que el Rey renunciaba a la Corona por sí y por sus hijos y sucesores. El detonante final de esta transcendental decisión regia la constituyó la denominada "cuestión artillera», al firmar contra su voluntad el Rey Amadeo la disolución y reorganización de nueva planta del arma de artillería.

Tras la lectura del mensaje se resolvió que se reuniesen en una sola Cámara ambos Cuerpos Colegisladores como depositarios de la soberanía nacional y acordar lo que mejor procediese para los intereses generales de la Nación.

Conforme a este planteamiento, Nicolás M. ${ }^{a}$ Rivero convocó a las dos Cámaras conjuntamente. Y, en esa misma sesión del día 11, una proposición suscrita por los republicanos Pi, Figueras y Salmerón solicitaba para la Asamblea Nacional todos los poderes y se declaraba la forma republicana de Gobierno.

La proposición fue sometida a votación -en un ambiente decididamente republicano en las calles-, produciéndose el resultado siguiente: 258 votos favorables a la proposición y 32 contrarios. Así era proclamada la I República en España.

Hay que destacar en este cambio de régimen dos circunstancias importantes: a) por una parte, como ha escrito Lacomba se producia "un cambio de régimen sin violencia", con la simple aprobación de un instrumento parlamentario como fue la proposición presentada por los republicanos; b) pero, por otro lado, justamente por haberse operado 
el cambio de régimen así, la República no fue traída, como escribe Torres del Moral, por unas Cortes republicanas tras un proceso constituyente, sino por unas Cortes monárquicas; en ellas, los republicanos auténticos eran una nueva fracción del Partido Demócrata.

Debe ser recordado que el artículo 47 de la Constitución de 1869, prohibía la deliberación conjunta de las Cámaras; y que el artículo 74.4, sometía a autorización legal la abdicación regia, en tanto que lo que se hizo fue tan sólo un intercambio de mensajes (Torres del Moral); la proclamación de la República significaba la derogación del artículo 33 de la Constitución, que establecía la forma monárquica, y ello se hizo sin respetar los cauces previstos en los artículos 110 y siguientes de la Constitución vigente en ese momento, que regulaban el procedimiento de reforma constitucional; en fin, otros muchos preceptos constitucionales se vieron afectados por el cambio de régimen (nombramiento del gobierno, disolución de las Cámaras, suspensión de las sesiones, concepción plural del Estado, etc.), sin que fueran abrogados los preceptos vigentes. A mayor abundamiento ni la convocatoria ni la organización de los debates se atuvieron ni al Reglamento del Congreso en ese momento en vigor (el de 1867) ni tampoco al Reglamento senatorial de la Monarquía de septiembre.

Lo cierto es que en aquella misma sesión de proclamación de la República todas estas dudas se presentaron a los diputados y senadores. Entre los que se manifestaron claramente opuestos a la aprobación de la proposición que postulaba el cambio de régimen estaba Álvarez Bugallal, que la consideraba contraria a la Constitución y a los Reglamentos vigentes; otros, con gran peso en las Cámaras como Ruiz Zorrilla, se mantuvieron dentro de una postura ambigua al declararse ni monárquico ni republicano; finalmente, correspondió a la facción republicana defenderse de las objeciones que se plantearon para la proclamación de la República: respecto a la abdicación, Castelar afirmó que la necesidad de una Ley estaba referida a la abdicación personal del monarca, pero no era extensiva a toda la dinastía; en cuanto a la reunión conjunta de las Cámaras, replicó Castelar que venía exigida por lo extraordinario de las circunstancias. Pero el argumento más decisivo del Gran Tribuno estuvo en mantener que por encima de la Constitución y de los Reglamentos parlamentarios estaba la soberanía y la democracia, que él consideraba en peligro tras la renuncia de Amadeo y la dimisión del gobierno de Ruiz Zorrilla ${ }^{11}$.

11 Vid. "Mensaje de la Asamblea al Rey", redactado por Emilio CASTELAR y que las Cortes aprobaron (Diario de Sesiones de 12 de febrero de 1873). 
En definitiva, como apunta Artola, la decisión de la Asamblea Nacional a favor de la República vino a darles a los republicanos inesperadamente el poder cuando más lejos se encontraban de conquistarlo; por tanto, "hubo que aprovechar felizmente las circunstancias", como también diría el propio Castelar.

Las elecciones de mayo de 1873 dieron un triunfo apoteósico a los candidatos republicanos-federales, aunque dicha victoria electoral se vio empañada por una altísima abstención. En cualquier caso esa victoria en las urnas ratificó a posteriori la proposición republicana, otorgando una apariencia de "Cortes Constituyentes" a la reunión conjunta de Cámaras del día 11 de febrero de ese año.

A Figueras, que había sido el alma del movimiento que llevó al triunfo el sistema republicano en 1873, y que abandonó la presidencia y el país en circunstancias aún no muy explicadas ${ }^{12}$, le sustituyó $\mathrm{Pi}$ y Margall el día 11 de junio de 1873, iniciándose la segunda etapa de la República, conocida como la fase "republicana democrática federal». La influencia anarquista en el federalismo transformó este último en "cantonalismo" (Pierre Vilar), y los cantones se proclamaron independientes. Pi tuvo que dimitir el 18 de julio al no contar con el apoyo de los «intransigentes" de su partido y al no querer emplear la violencia para sofocar el movimiento cantonalista.

Durante la tercera etapa de la I República, se coloca al frente de la misma Nicolás Salmerón, quien se apresuró a tomar medidas enérgicas contra el cantonalismo, pues a imitación de Cartagena, iban surgiendo núcleos del movimiento en Valencia, Sevilla, Cádiz, Alicante, Salamanca y otras poblaciones. Por el Decreto de 20 de julio de 1873 se declaraba pirata a la escuadra sublevada en Cartagena. $Y$, mientras se luchaba por reducir el cantón cartagenero, Salmerón abandonó el poder por la proposición de Modesto Martínez Pacheco, para el restablecimiento de la pena de muerte como medio de acabar con la indisciplina militar, que acabó siendo dictaminada favorablemente por el Congreso.

12 Fernández Rúa, J. L., en su obra 1873. La Primera República, Tebas, pág. 326 , recoge la carta explicativa que dio Figueras de su abandono a un amigo residente en La Habana el 3 de septiembre de 1873; entre esas razones arguye algunas personales, como el fallecimiento de su esposa en abril de ese año, y otras políticas como las tensiones que sufría desde su propio partido y la actitud amenazadora de los monárquicos (vid. también, CONDE DE ROMANONES, Los cuatro Presidentes de la Primera República, págs. 42 y ss.). 
Llegaba así la República a su última y definitiva fase bajo la presidencia de Castelar (7 de septiembre de 1873), quien representaba el republicanismo unitario y autoritario. Para controlar la situación solicitó y obtuvo de las Cortes "autorizaciones extraordinarias", suspendiendo estas últimas sus sesiones hasta el 2 de enero de 1874. Entre las medidas adoptadas por Castelar estaban el restablecimiento del cuerpo de Artillería que había disuelto Ruiz Zorrilla y la suspensión de las garantías constitucionales. Cuando las sesiones parlamentarias se reabrieron ese día, Castelar fue derrotado por escaso margen al solicitar el voto de confianza; en la madrugada del día 3, los generales Pavía y Rodríguez de Alburquerque, disolvían y desalojaban de sus escaños a los diputados allí presentes. La República había llegado a su fin. Al parecer, Castelar conocía los planes de Pavía, quien le había manifestado que apelaría a la fuerza si el Gobierno era derrotado en las Cortes. Con este episodio finaliza el llamado sexenio revolucionario, habiéndose dado durante el breve período republicano las etapas de toda revolución clásica, apunta Ferrando: un primer momento no deseado, una situación radical y una reacción de signo reaccionario.

Pero, entre tanto, cabe preguntarse: ¿en qué términos estaba vigente la Constitución de 1869 y, por tanto, sus Reglamentos parlamentarios? Bien es sabido que el proyecto de Constitución no llegó nunca a aprobarse. Por eso la importancia de conocer el grado de vigencia de la Constitución de 1869 , que nunca fue expresamente derogada; al no aprobarse la Constitución republicana, la del año 1869 continuó en vigor, incluso después del golpe de Estado del general Pavía (Tomás y Valiente). Es ésta quizá una de las razones que justificaron la vigencia formal del Reglamento del Senado de 1871 durante el crucial año de 1873 , si bien esa vigencia no tuvo virtualidad real sino a partir de las elecciones de mayo de 1873.

B) El bicameralismo imperfecto del Parlamento republicano en el proyecto federal de 1873 como marco de referencia del Reglamento "interino" de las Cortes Constituyentes de 1873

El proyecto de Constitución federal de 1873 representa el modelo más acabado del bicameralismo imperfecto dentro de nuestro Dere- . cho público histórico. Congreso y Senado tienen distintas funciones y sus miembros se reclutan por procedimientos distintos.

Ello era así por la estructura federal del Estado; el Congreso simbolizaba la unidad de la Nación española: «El Congreso se compondrá de diputados, debiendo haber uno por cada 50.000 almas, y siendo 
todos elegidos por sufragio universal directo" (art. 51); mientras que el Senado representaba la existencia de los Estados regionales: «los senadores serán elegidos por las Cortes de sus respectivos Estados, que enviarán cuatro por cada Estado, sea cualquiera su importancia y el número de sus habitantes « (art. 52).

Pero para que ninguna de las Cámaras se hiciese hegemónica con respecto a la otra se establece un período de legislatura idéntico para ambas: "Las Cortes se renovarán en su totalidad cada dos años" (art. 53).

Los poderes, como hemos dicho, eran distintos para ambas Cámaras. El Congreso retenia los tradicionales poderes legislativos; y al Senado, que ni siquiera tenía la iniciativa de las leyes (art. 70), se le atribuían funciones fiscalizadoras respecto a la legislación producida por el Congreso, estatuyéndose un control de constitucionalidad para depurar las normas contrarias a los derechos de la personalidad humana, o los poderes de los organismos políticos, o las facultades de la Federación, o el Código fundamental (art. 70).

Este control previo de constitucionalidad, sin precedentes en nuestro Derecho público histórico, podía retener la entrada en vigor de una Ley hasta un plazo de tres años (veto suspensivo) a cuyo término, de persistir el Senado en la declaración de inconstitucionalidad, se promulgará por el Presidente convirtiéndose en Ley en toda la Federación sin perjuicio que el Tribunal Supremo de la Federación declarase en su aplicación la constitucionalidad o no de la Ley en cuestión (art. 70 in fine, en relación con el artículo 77). Esta extraordinaria facultad de la Cámara Alta no tuvo reflejo alguno en el Reglamento del Senado; por lo que de haberse planteado el supuesto contemplado en el artículo 70 del proyecto de Constitución, no hubiese existido procedimiento hábil para hacer eficaz esa fiscalización.

Finalmente, se producia también concurrencia en las funciones judiciales atribuidas a ambas Cámaras: el Congreso acusaba ante el Senado al Presidente y a los ministros; el Senado declaraba si había lugar o no a la formación de causa, correspondiendo al Tribunal Supremo juzgarlos y sentenciarlos (art. 67).

\section{C) El Reglamento interino republicano como instrumento de organización y funcionamiento de las Cortes Constituyentes}

La disolución, no sin problemas, de la Comisión Permanente y la posterior celebración de las elecciones dio lugar a unas Cortes Cons- 
tituyentes que priorizó entre sus objetivos más inmediatos la elaboración de un Reglamento interino que sirviera de vehículo para proceder al examen de las Actas de los Diputados al fin de configurar definitivamente la organización y el funcionamiento de las Cortes, y que sirviera también de instrumento para la elaboración de las leyes ordinarias y del control parlamentario sobre la acción del Gobierno, todo ello desde la perspectiva que otorga el nuevo régimen político.

Bajo estas circunstancias la presidencia de Salmerón dictó el 5 de agosto de 1873 el Reglamento interino de las Cortes Constituyentes, cuya vigencia fue efímera porque tras el golpe del general Pavía el 3 de enero de 1874 fue sustituido, sin especial fórmula de derogación y de manera expeditiva, por el Reglamento isabelino del Congreso de 1847, que extendió su vigencia, con algunas reformas hasta 1918. En cualquier caso, el Reglamento interino republicano no se separó prácticamente de la dicción literal que le marcó el Reglamento senatorial monárquico de 1871 , siguiéndose las mismas pautas respecto al examen de Actas y constitución definitiva de las Cortes (Títulos IV y V), elección del Presidente, Vicepresidentes y Secretarios y atribución de sus respectivas competencias (Títulos VI y VII). Sin embargo, se introduce en este Reglamento una importante novedad: desaparecen las Secciones como órganos funcionales de trabajo, configurándose las Comisiones (permanentes o especiales) como los auténticos órganos de trabajos de las Cortes (Título IX). También se realza en este Reglamento el papel institucional de la Mesa, que pasaba a ser la encargada de autorizar la lectura de las proposiciones de ley que formulasen los Diputados (art. 71), en detrimento del Presidente. El fundamento de este cambio pudo estar en el carácter asambleario del sistema político vigente durante 1873.

En cuanto a las funciones de control parlamentario sobre el Gobierno (Títulos XIV y XV) el Reglamento interino republicano dio un significativo paso hacia delante al distinguir con nitidez entre preguntas e interpelaciones, al considerar las segundas como una consecuencia de las primeras y al fijar el plazo del ejercicio de la interpelación en "no más de siete días". Y Asimismo, dentro de una concepción y un lenguaje que ya resultan muy actuales, se concibe la interpelación como un presupuesto habilitante para presentar los Diputados las proposiciones que creyesen conveniente (art. 127). Pero todo ello dentro de la paradójica situación de que el proyecto de Constitución federal -a diferencia de la Constitución monárquica de 1869- no hacía referencia explícita alguna al control parlamentario del Gobierno, no obstante su vocación asamblearia. 
Asimismo, el control parlamentario con responsabilidad política en el Reglamento republicano aparece formalizado en términos casi semejantes a los reconocidos a la Asamblea francesa durante la III República, al establecer que los votos o proposiciones de censura, que debían estar también firmados por siete Diputados, así como los de gracias (que no estaban sujetos a esa formalidad), no pasasen a las Secciones, sino que se abría la posibilidad de que fueran discutidos directamente en Sesión plenaria. De hecho, en la práctica, así ocurrió en dos ocasiones: bajo la presidencia de Pi y Margall, éste solicitó la "completa confianza" del Gobierno a través de la correspondiente moción que fue finalmente aprobada por 179 votos a favor y 49 en contra ${ }^{13}$; y ya en las horas crepusculares de la I República, su presidente, Castelar, pidió un voto de gracia para el Gobierno en la madrugada del día 3 de enero de 1874, que puesto a votación fue derrotado por 120 votos contra 10014; a continuación dimitido el Gobierno y cuando se iba a proceder al nombramiento de otro Diputado como presidente, tras el correspondiente receso, y siendo las 7,55 horas de las mañana, el Presidente del Congreso, D. Nicolás Salmerón anunció la orden del Capitán General de que se desalojara el hemiciclo.

Aunque obvio es decirlo, el Reglamento interino ya estaba en vigor cuando se estaba elaborando por las Cortes Constituyente el proyecto de código político de república federal, se atribuía en el artículo 138 de esa norma reglamentaria el que las Cortes «adoptasen la resolución que juzgasen necesaria, a solicitud de la Comisión Fiscal para reparar las infracciones constitucionales o de amparo de algún derecho violado". Pero este precepto no fue tenido en cuenta por los defensores de la legalidad vigente frente al golpe del General Pavía para mantener viva la república federal, muy al contrario Salmerón obviando la vía que le abría ese significativo precepto reglamentario optó por denunciar el hecho ante el Tribunal Supremo, lo que resultó a la postre completamente baldio.

Por último, se ha de hacer notar que el Reglamento interino de 1873, además de suprimir como es lógico toda alusión a los discursos de la Corona y mensajes al Rey, eliminó todo tratamiento jerárquico (art. 167), en coherencia con la fachada ideológica republicana del régimen político febrerista.

14 Vid. Fernández Rúa, J. L.: 1873, La Primera República, Ed. Tebas, pág. 505. 


\section{El fin del sexenio: Reglamentos parlamentarios durante el Gobierno autoritario de Serrano. La vuelta a los Reglamentos isabelinos en la Cámara Baja y mantenimiento del Reglamento senatorial de 1871}

Después del golpe de fuerza del general Pavía al Congreso, éste entregó el Gobierno al general Serrano quien formó un Ministerio en el que estaban presentes las tendencias conservadoras, radical y republicana unitaria, pero al que no se quiso unir la preeminente figura del momento: Castelar ${ }^{15}$.

El Gobierno publicó el 9 de enero de 1874 un Manifiesto a la Nación decretando lo siguiente: 1873.

"Artículo $10^{\circ}$ Se declaran disueltas las Cortes Constituyentes de

Artículo $2 .^{\circ}$ El Gobierno de la República convocará a Cortes Ordinarias tan luego como, satisfechas las necesidades del orden, pueda funcionar libremente el sufragio universal».

La parte preambular del Manifiesto recogía su plena fidelidad a los principios revolucionarios de septiembre y a la Constitución de 1869, a la que se declaraba en vigor pero se suspenderá temporalmente en sus efectos "para que... resplandezca y domine una vez vencida como esperamos, la anarquía material y moral que hoy nos devora".

Régimen político de difícil calificación el que presidió Serrano; porque si bien en lo formal era republicano, pero sin constitución republicana, tampoco respondía a los esquemas monárquicos de la Constitución suspendida de efectos; por ello, el Gobierno de Serrano era un "macmahonismo" sin solución de futuro alguno, atenazado como estaba por la guerra colonial de Cuba y la civil carlista. Asi este régimen de imposible calificación política, cayó a su vez tras el levantamiento protagonizado por el general Martínez Campos en Sagunto el día 29 de diciembre de 1874, por el que se proclamaba Rey de España al hijo de Isabel II, don Alfonso XII, abriéndose un nuevo período constitucional con la Restauración borbónica.

15 Al ofrecérsele a Emilio Castelar que se uniese al nuevo Gobierno, incluso asumiendo la Presidencia del mismo, contestó a quien le había hecho el ofrecimiento en nombre del general Pavía: "Dígale usted al general que mi dignidad me impide hacer tal cosan (vid. Portillo, E. M. del, y Primelles, C., Historia política de la I República Española, pág. 148, Madrid, 1932. 
Durante el tiempo que transcurre entre el 9 de enero de 1874, fecha del Manifiesto y el 29 de diciembre del mismo año, al estar disueltas las Cámaras, no hubo actividad parlamentaria alguna, por lo que también estuvieron en suspenso tanto el Reglamento de la Monarquía constitucional de 1871 como el republicano de 1873.

Durante 1875 - sobre todo a partir de mayo de $1875^{16}$ - todas las reuniones $y$ debates habidos en el Senado se hicieron ya bajo los auspicios de su Reglamento de 1871. Y después de las elecciones generales convocadas el 31 de diciembre de 1875 y realizadas del 15 al 20 de febrero de 1876, los Diputados dieron por derogado sin especial pronunciamiento el Reglamento de 1873 declarando en pleno vigor el Reglamento de 4 de mayo de 1847, que a su vez, promulgada la Constitución de 2 de julio de 1876, sufrió sucesivas modificaciones, como fueron: la de 16 de diciembre de 1878, de 7 de abril de 1888, de 10 de abril de 1883, 18 de junio de 1887, de 7 de abril de 1894, de 23 de febrero de 1895 y 24 de julio de 1896, con esta última versión funcionó la Cámara Baja hasta el dictado el 4 de mayo de 1918, que a su vez estaría en vigor hasta la II República, que se otorgó un Reglamento provisional de las Cortes Constituyentes de 18 de julio de 1931, en el que se deliberó y aprobó la Constitución de 1931 ateniéndose a lo dispuesto en su Título IV (Discusión del proyecto de Constitución) y al Reglamento definitivo del Congreso de los Diputados de 29 de noviembre de 1934.

Por el contrario el Reglamento senatorial de 1871, sobrevivió con buena salud al marco jurídico-político en el que fue dictado, sufriendo sólo la reforma de varios de sus artículos el 21 de junio de 1877 y manteniéndose en vigor hasta el Reglamento senatorial de 16 de mayo de 1918; que todo hay que decirlo fue muy tributario de su precedente.

16 La fecha concreta es el 20 de mayo de 1875, en la que tuvo lugar mediante convocatoria de Cánovas de todos los ex-parlamentarios -más de quinientosuna reunión en el Senado, actuando de presidente Luis Mayans, para establecer las bases político-constitucionales del régimen de lo que se llamaría «La Restauración». En ella se aprobó una proposición por la que se optaba por el advenimiento de la Monarquía borbónica en la persona de Alfonso XII y por la constitución de una Comisión de Notables para preparar la nueva Constitución. 